\title{
TIPOLOGÍA Y SERIACIÓN DE LA CERÁMICA PROVENIENTE DEL CEMENTERIO CHIMÚ DE HUACA DE LA LUNA, PERÚ
}

\author{
TYPOLOGY AND SERIATION OF CERAMICS FROM THE CHIMÚ CEMETERY \\ OF HUACA DE LA LUNA, PERU
}

Feren CAstillo Luján ${ }^{A}$

El artículo presenta los resultados de estudios sobre la cerámica ritual obtenida del primer cementerio chimú excavado en su totalidad al interior de la Huaca de la Luna, en el valle de Moche (Perú). Se ofrece una tipología de formas completas de vasijas, figurinas, ornamentos e instrumentos de producción. Asimismo, se ha realizado la seriación de estos elementos según las cuatro fases conocidas (Chimú Temprano, Medio, Tardío y Chimú-Inca). Finalmente, los fechados radiocarbónicos de dos tumbas de la primera fase, el patrón funerario y el análisis morfológico e iconográfico de las vasijas abren nuevas perspectivas sobre los inicios de la sociedad chimú.

Palabras clave: Chimú, tipología, seriación, cerámica, Huaca de la Luna.

This article presents the results of studies on ritual ceramics obtained from the first chimu cemetery excavated entirely inside the Huaca de la Luna, Moche valley (Peru). It includes a typology of complete shapes of vessels, figurines, ornaments and instruments of production. In addition, these elements have been seriated according to the four known phases (Early, Middle and Late Chimú, and Chimú-Inca). Finally, the radiocarbon dating of two tombs from the first phase, the funeral pattern, and the morphological and iconographic analysis of the vessels open new perspectives on the beginnings of the chimu society.

Keywords: Chimu, typology, seriation, ceramics, Huaca de la Luna.

\section{INTRODUCCIÓN}

La sociedad chimú ocupó un espacio de más de $500 \mathrm{~km}$ a lo largo de la costa norte de Perú entre 1000 y 1460 DC hasta la interrumpción por la conquista incaica. Los inicios de esta sociedad se ubican tras el declive del modelo político moche, el que siglos antes dominara el mismo territorio chimú. El fin de los moches trajo consigo la formación de dos señoríos: Lambayeque al norte, en los valles de Lambayeque, Zaña y Jequetepeque, y Chimú al sur, en los valles de Moche, Chicama y Virú como la parte nuclear del territorio.

La expansión chimú corresponde a un segundo momento, en el cual incorporan los valles al norte y al sur del río Moche, construyéndose grandes centros provinciales: Farfán en el valle de Jequetepeque, Manchán en el valle de Casma y Túcume en el valle de La Leche (Mackey 2013). No obstante, la ocupación chimú estuvo presente en otros sitios menores a lo largo del territorio controlado (fig. 1).

Chan Chan, ubicado al norte del río Moche, fue el principal centro administrativo chimú. Este coloso de adobes estaba constituido por diez "ciudadelas", llama-

\footnotetext{
A Feren Castillo Luján, Arqueólogo Investigador del Proyecto Arqueológico Huacas del Sol y de la Luna, Universidad Nacional de Trujillo. Av. 28 de Julio 470, Urbanización Torres Araujo, Trujillo, Perú, E-mail: ferencastillo@hotmail.com
} 
dos hoy conjuntos amurallados, cuyas características arquitectónicas eran patios de audiencias y de depósitos, cocina, lugares de reuniones, canchones y plataformas funerarias (Day 1980, Ravines 1980a). Tales plataformas estaban formadas por diversas cámaras, en las cuales se inhumaba al personaje principal rodeado de una gran cantidad de ofrendas (Conrad 1980). Day (1980) sugirió que estos palacios eran residencias de élites o de personas de alto estatus, sin embargo, posteriormente se propuso que estos debieron funcionar como áreas ceremoniales (Piminchumo 2004).

A partir de los trabajos de Donnan y Mackey (1978) se sugirió por primera vez que la ocupación chimú en el valle de Moche se dividía en cuatro fases: Chimú Temprano, Medio, Tardío y Chimú-Inca. Hasta ese entonces, se creía que los entierros de las fases Temprana y Media se realizaban en fosas irregulares e intrusivas al interior de las plataformas de adobes de las huacas edificadas durante la época Moche; no obstante, hallazgos recientes han reportado tumbas con el mismo comportamiento para las fases más tardías.

Con respecto a las prácticas religiosas, Ravines (1980b) identifica tres categorías: el culto oficial y los grandes oráculos, los cultos provinciales o locales y el culto a los muertos. Este último fue muy importante para los chimús y comprendía una serie de cortejos fúnebres, destacando la procesión del féretro con el cuerpo del munao, malqui o ancestro. Tales ceremoniales dedicados al ancestro fueron representados en maquetas de madera, en las que se observa el culto al rey chimú al interior de los palacios "ciudadelas" (Uceda 2008).

El complejo ceremonial de las Huacas de Moche, conocidas también como Huacas del Sol y de la Luna, corresponde a una antigua ciudad construida al sur del río Moche entre los siglos I y IX DC (Uceda 2010). Tras su abandono definitivo por parte de la sociedad moche, el sitio fue reocupado con frecuencia como un lugar sagrado. Posiblemente se convirtió en un "santuario a los ancestros" durante la sociedad chimú (Castillo 2013).

Las nuevas evidencias que aporta este artículo provienen del primer cementerio chimú excavado en su totalidad, emplazado en el sector Terrazas de Huaca de la Luna (fig. 2). Este sector está constituido por dos terrazas construidas en la época Moche (último edificio de Huaca de la Luna).

Las cinco temporadas de excavación en el sector Terrazas han permitido identificar un total de 126 contextos funerarios (Gamboa \& Uceda 2008, Orbegoso et al. 2011, 2012, 2013, Rojas et al. 2014). En la última temporada se realizaron las primeras interpretaciones sobre el patrón funerario y rango social de los individuos inhumados en el cementerio.

La muestra analizada está constituida por 2100 objetos provenientes de 52 tumbas (E2, E3, E4, E6, E7, E9, E11, E12, E13, E14, E22, E25, E27, E28, E29, E30B, E32, E33, E35, E38, E40, E43, E44, E45, E46, E49, E50, E52, E55, E56, E57, E58, E62, E64, E70, E74, E75, E79, E83, E85, E86, E90, E92, E99, E100, E106, E111, E112, E116, E119, E124 y E126). Cabe destacar que la mayoría de las tumbas empleadas en este estudio son de contexto primario, salvo E2, E14, E38, E40, E99, E100, E106 y E119. Estas últimas, pese a presentar evidencias de manipulación postentierro, fueron incluidas en la muestra por poseer formas que permitían mejorar la propuesta tipológica.

\section{ANTECEDENTES}

El material recuperado (vasijas) por Uhle (1913) en las Huacas del Sol y de la Luna fue analizado por Kroeber (1926), corroborando la propuesta de Uhle sobre la existencia de varios estilos, como Proto-Chimú (actualmente conocido como Moche), Tiahuanacoide, Tricolor Geométrico, Trípode Cursivo, Cursivo Modelado, RojoBlanco-Negro Recuoide y Chimú Tardío. Este último correspondería a la cerámica ordinaria de cocción reductora, cuyas formas representativas son señaladas de la siguiente manera: asa estribo, doble pico, cabeza y pico, figura y pico, doble jarra con puente, jarra con mango plano, jarras sin mango, tipos especiales, jarra figura y aríbalos.

Años más tarde, Larco (1948), teniendo como referencia el material recuperado en sus excavaciones, estableció siete épocas para las culturas de la costa norte: Precerámica, Inicial de la Cerámica, Evolutiva, Auge, Fusional, Imperial y de la Conquista. Larco (1938, 1939, 1945) descarta el uso del término Proto-Chimú para la cerámica bicroma de la época Auge, la cual denomina como Mochica. Para la época posterior (Fusional), Larco (1948) propuso tres períodos: Período Inicial (Huari norteño A y Mochica-Huari), Período Medio (Huari norteño B y Lambayeque) y Último Período (HuariLambayeque y Cajamarca). De igual manera lo hizo para la época Imperial (Chimú, Inca y Chimú-Inca). Por otro lado, las excavaciones en el valle de Virú (Ford \& 


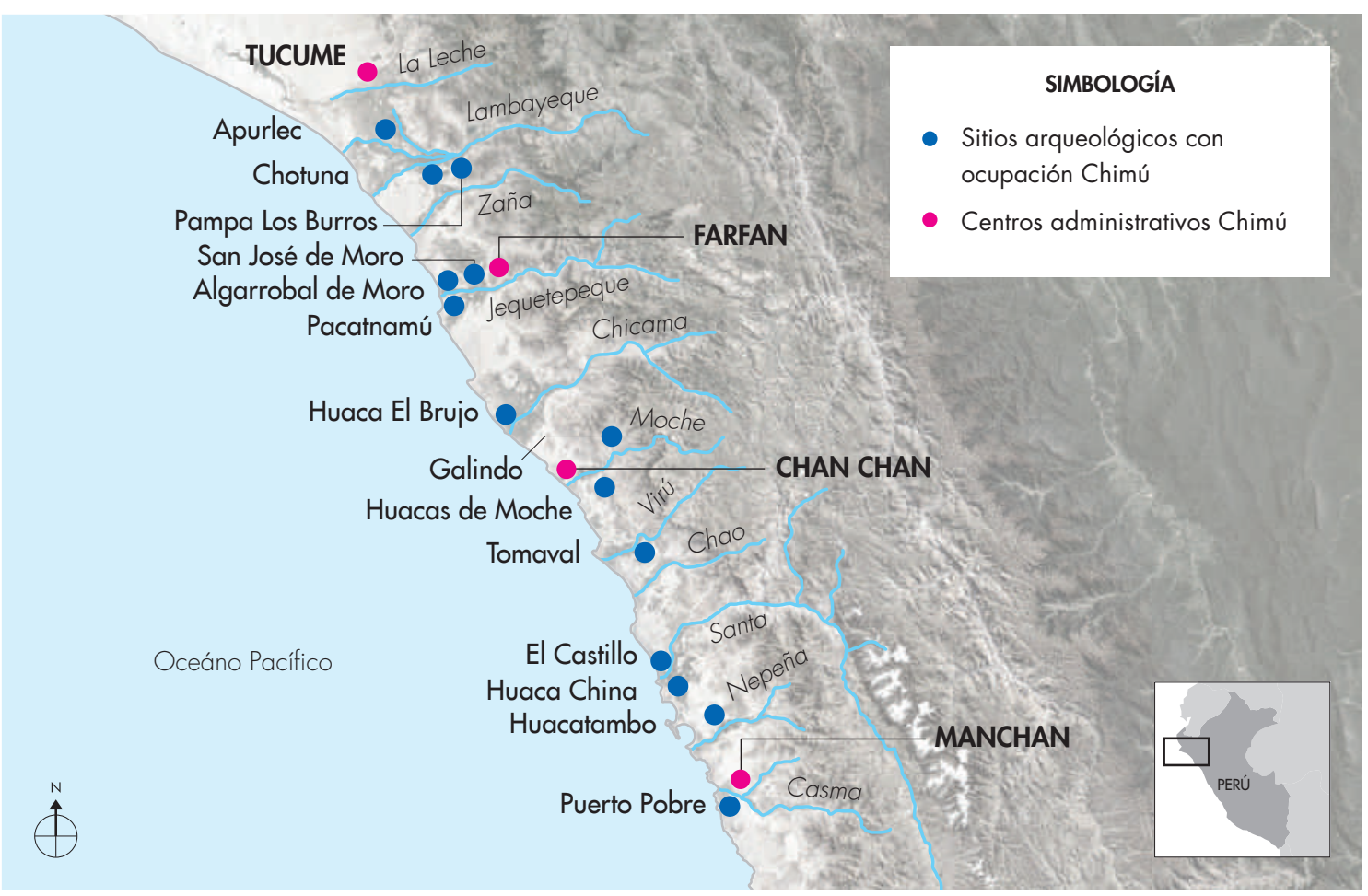

Figura 1. Plano de la costa norte del Perú en que se indican los principales sitios mencionados en el texto. Figure 1. Map of the northern coast of Peru showing the main sites mentioned in the text.

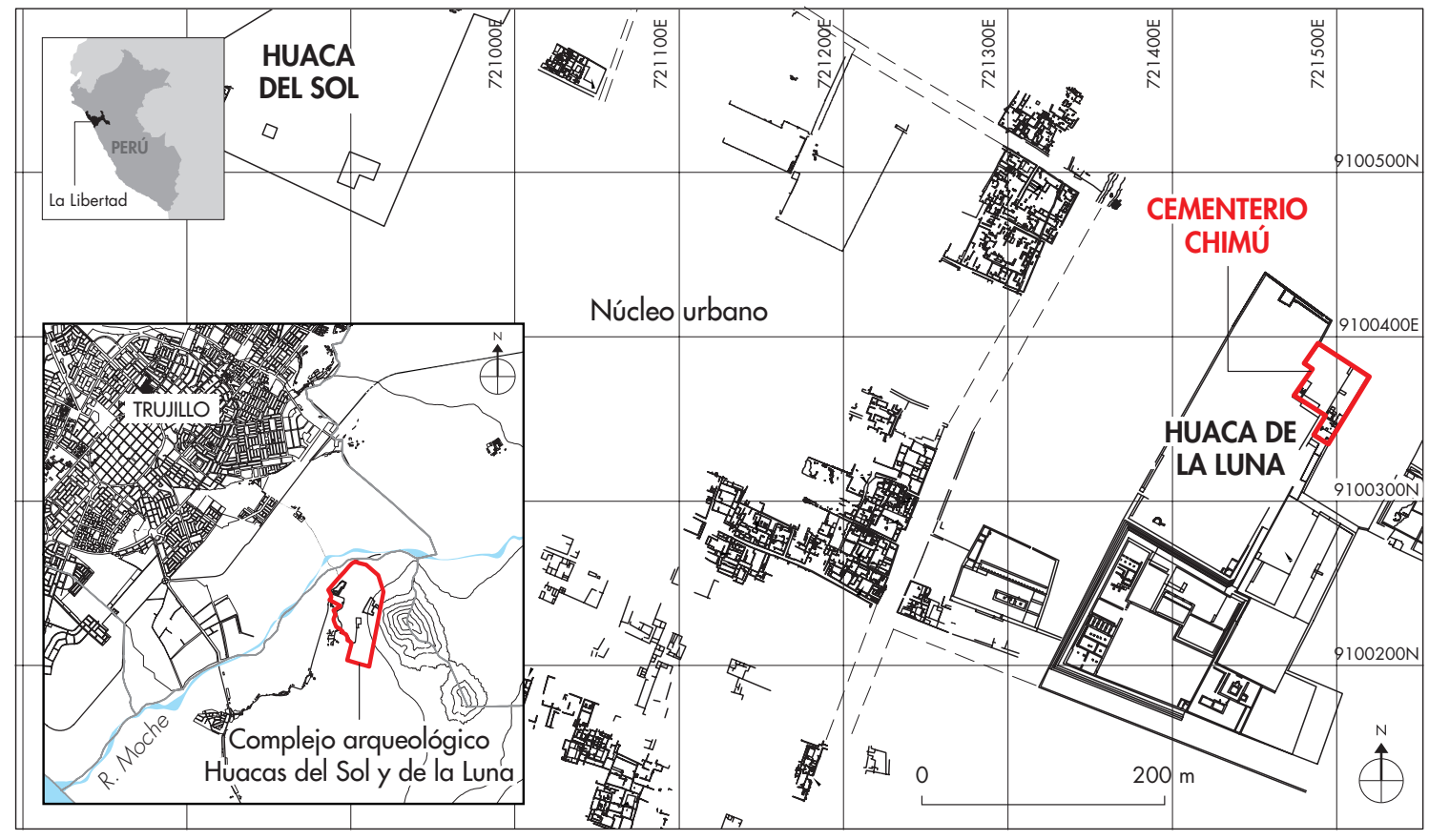

Figura 2. Plano de ubicación del cementerio chimú en el Complejo Arqueológico Huacas del Sol y de la Luna. Figure 2. Map showing the location of the Huacas del Sol site and location of the Chimu cemetery within the Huacas del Sol y de la Luna Archeological Complex. 
Willey 1949, Collier 1955) permitieron identificar siete períodos, que de cierta manera se correlacionaban con los de Larco: Guañape (Inicial de la cerámica), Puerto Morín (Evolutiva), Gallinazo, Huancaco (Auge), Tomaval (Huari-Lambayeque), La Plata (Chimú) y Estero (Chimú-Inca).

Larco (1939) también denominó la cerámica Huari-Lambayeque como Tiahuanacoide del Norte Decadente. El autor indica que es similar a la Chimú, pero con formas modificadas del Período Auge (Mochica). Sin embargo, en ella predominarían las formas Lambayeque, llamadas también de estilo Abigarrado, debido a su excesiva decoración pictórica. Con respecto a la cerámica Chimú, el autor (Larco 1939) hace hincapié en las formas heredadas, tales como el pico y el puente Huari, el asa estribo Mochica, la base troncocónica y la decoración con asas Lambayeque. Asimismo, señala otras formas, como las botellas de doble pico y puente, doble recipiente (cuerpo) con pico y puente, triple y cuádruple recipiente unido por asa de estribo, porongos (¿cántaros?) de gollete recto, ollas y platiformes (platos) de base circular y trípode. Finalmente, para la época de fusión cultural armoniosa entre la cerámica Chimú e Inca, los productos derivados se caracterizan por la reducción del tamaño de los vasos (botellas), la fuerte presencia del cuello acampanulado y los rasgos derivados de la forma aribaloide.

En los años setenta, en el marco del Proyecto Chan Chan-Valle de Moche, Donnan y Mackey (1978) elaboraron una primera división de sus contextos funerarios, agrupándolos en cuatro fases relativas: Chimú Temprano, Chimú Medio, Chimú Tardío y Chimú-Inca. La primera correspondería al Período Tomaval del valle de Virú; a su vez, esta sería la llamada cerámica Rojo-NegroBlanco Recuoide, por Kroeber, y Huari-Lambayeque, por Larco. Las fases Media y Tardía se identificarían con el Período La Plata, de Ford y Willey, así como Chimú Tardío, de Kroeber, y Chimú, de Larco. Finalmente, la fase Chimú-Inca equivaldría al Período Estero, de Ford y Willey, y Chimú-Inca, de Larco. Sin embargo, los autores no ofrecieron una tipología de la cerámica recuperada en sus excavaciones, confundiendo algunos estilos foráneos dentro de la seriación de tumbas, sobre todo para la fase Temprana.

Posteriormente, Mackey (1985) propuso una tipología de la cerámica Chimú 1 o Early Chimu, tomando como muestra los hallazgos en los valles de Moche y Virú. La autora identifica cuatro categorías o tipos ge- nerales: cántaros (cántaros, cántaros con cuello efigie y cántaros con asa), cuencos (base redonda baja, base redonda alta, trípode y plana), ollas y formas con pico (vasijas efigie con pico, pico y asa, doble pico, efigie y asa y vasijas de doble cuerpo). Mackey (1985) sugiere que la primera fase Chimú recibió influencia de varias sociedades, como la moche, la huari y la pachacamac, culturas del extremo norte y serranas; además, afirma que este estilo se caracteriza por ser una estandarización de motivos en tres colores (rojo-blanco-negro) que responde a un sincretismo cultural ocurrido a finales del Horizonte Medio.

En el valle de Jequetepeque, Donnan (1997) reportó un centro de producción artesanal de cerámica ChimúInca. El autor identificó formas derivadas del estilo Inca y formas locales de uso doméstico consistentes en ollas, cántaros, botellas y cuencos. Luego, en el marco del Programa Arqueológico San José de Moro, Prieto (2008) ofreció una propuesta tipológica de las formas utilitarias del Período Chimú en el Ârea 35 consistente en dos subfases: Chimú Tardío A (la más temprana y relacionada con las fases i y i del sitio) y Chimú Tardío $\mathrm{B}$ (relacionada con la fase III del sitio, la más tardía).

El autor (Prieto 2008) plantea una tipología compuesta por 20 tipos de formas cerradas, consistentes en ollas (medio campana, convexo, recto convexo, sin cuello, globular, plataforma, recto, evertido, carenado plataforma, carenado, carenado alto y expandido); cántaros (evertido, recto-evertido, recto, recto entrante y gollete carenado); botellas (expandido, recto-evertido y recto); y 15 tipos de formas abiertas, compuestas por platos (labio evertido, expandido, evertido, labio plano, hondo y carenado externo); escudillas (evertido-labio gancho, recto-labio gancho, expandido, recto con labio evertido y recto); paicas (entrante y recto) y, finalmente, los ralladores (entrante y carenado). Esta propuesta tipológica es la más compleja -hasta la fecha- de la cerámica Chimú; no obstante, algunos tipos comparten rasgos que podrían unificarse y demandar una considerable reducción de subtipos.

Volviendo al valle de Moche, las últimas investigaciones en Galindo han revelado nuevas evidencias sobre el Chimú Tardío. La mayoría de fragmentos de cerámica fueron recuperados en diversas estructuras ubicadas en la ladera A del cerro Galindo; estos son de cocción reductora y sus formas comunes corresponden a ollas (de cuello carenado y cuello evertido) y platos (Lockard 2008). 
Un apartado especial merecen los trabajos realizados durante más de 25 años por el Proyecto Arqueológico Huacas del Sol y de la Luna. Desde 1991, bajo la codirección de Santiago Uceda, se han reemplazado sistemáticamente viejos paradigmas y aportado nuevos conocimientos sobre la sociedad moche o mochica. Asimismo, desde las primeras intervenciones se han descubierto tumbas intrusivas postmoches, especialmente Chimú, que insinuarían que el templo principal siguió considerándose como un lugar sagrado (Uceda 2010).

Los trabajos descriptivos relacionados con la cerámica en Huaca de la Luna se limitan a dos artículos. El primero corresponde a la tipología del llamado set utilitario Moche recuperado en una trinchera del núcleo urbano del conjunto arquitectónico 35 (Gamarra \& Gayoso 2008). Los autores definieron cinco tipos principales: cántaros, tinajas, ollas, cuencos y platos. Esta tipología fue elaborada a partir de fragmentos diagnósticos asociados a rellenos de ocupaciones domésticas cuyas formas no reflejan cambios en la secuencia del sitio, puesto que la manufactura de estas vasijas no era controlada por el aparato estatal. El segundo trabajo -más completo- es el catálogo de los productos de cerámica registrados en la ciudad de Huacas del Sol y de la Luna (Gayoso 2016). Su autor agrupa los elementos en: vasijas, instrumentos de producción artesanal, instrumentos musicales, ornamentos, utensilios de cocina y figurinas. Estas categorías han servido como muestra de referencia, junto con trabajos más completos, sobre las formas de la cerámica (Manrique 2001, Lumbreras 2005).

A continuación se presentan nuevos datos para entender la tipología y seriación de la cerámica Chimú en el valle Moche por parte del proyecto Huacas del Sol y de la Luna, datos que sirven de referencia para las recientes intervenciones arqueológicas sobre esta sociedad. No obstante, aún queda mucho por trabajar. Las últimas investigaciones han revelado cerámica del período de transición entre lo mochica y lo chimú, período que merece atención para poder entender las formas y cambios estilísticos de la cerámica entre estas culturas.

\section{EL CEMENTERIO CHIMÚ DE HUACA DE LA LUNA}

El cementerio chimú se ubica en la esquina noreste de la plaza principal de Huaca de la Luna (fig. 2). Este espacio estaba formado originalmente por un patio -Terraza 1- con tablado -Terraza 2- construido durante el esplendor del Templo Viejo de Huaca de la Luna (Período Teocrático del sitio). Tras el abandono del complejo, los chimús hicieron remodelaciones para obtener la forma en el cual fue encontrada. Las evidencias de estos acondicionamientos se muestran principalmente en la construcción de un pequeño trono ubicado en la esquina noroeste de la segunda terraza. Este presentaba hoyos con evidencias de haber contenido ídolos de madera similares a los ídolos registrados en el frontis norte del mismo templo (Tufinio 2012). Es probable que la destrucción de los muros de los límites sur y oeste de la primera terraza haya sido obra chimú para modelar la plataforma (fig. 4).

Cabe destacar que la primera terraza contenía un relleno distinto a otras partes del Templo Viejo. Aquí se construyeron cinco grandes celdas rectangulares (A, B, $\mathrm{C}, \mathrm{D}, \mathrm{E})$, cuyo interior se dividía con pequeños muretes formando celdillas, las cuales fueron rellenadas con arena del cerro de color beige. Finalmente, colocaron de manera uniforme adobes que actuaron como base para la construcción del último piso, el cual se conservaba en el lado este.

Los chimús no respetaron la arquitectura moche al momento de adaptar la Terraza 1 como cementerio. Todas las matrices son intrusivas. La excavación de las celdas B y C puso en evidencia un desmontaje ex profeso de los muretes que dividían las celdas y que, en muchos casos, emplearon los adobes como marcadores y/o delimitadores de matrices. Esto permitió a los chimús enterrar a sus difuntos de la fase Temprana en los niveles más profundos, mientras los más tardíos se encontraron cerca de la superficie. Así, solo en estas celdas se identifica una superposición cronológica de las tumbas a partir del ajuar alfarero que las acompañaba (fig. 5).

El $88,5 \%$ de las tumbas analizadas (46 casos) estuvieron distribuidas en la primera terraza y el restante ( 6 casos) en la segunda. Los análisis realizados sobre el ajuar funerario (Rojas et al. 2014) y las características paleográficas (Mejía 2014) muestran que la mayoría de los individuos exhumados pertenecen a un mismo grupo 
social, posiblemente de un rango medio o medio-bajo (tercer nivel, según Rojas et al. 2014).

Del análisis de las vasijas se han logrado diferenciar 25 tumbas de filiación Chimú Temprano (E3, E14, E25, E27, E32, E35, E43, E44, E46, E55, E56, E58, E62, E64, E70, E83, E85, E86, E90, E92, E100, E111, E116, E124 y E126), 18 de filiación Chimú Medio (E4, E6, E7, E9, E12, E13, E22, E28, E29, E30B, E45, E52, E57, E74, E75, E79, E99 y E106), 7 de filiación Chimú Tardío (E2, E11, E33, E38, E40, E49 y E50) y 2 de filiación Chimú-Inca (E112 y E119). Existe la siguiente disminución gradual entre las fases: fase Temprana: $48,1 \%$ de los casos estudiados; fase Media: 34,6\%; fase Tardía: 13,5\%; fase Chimú-Inca: 3,8\%. Esta reducción es considerable y podría relacionarse con el abandono del cementerio por parte de este grupo corporativo.

Por otro lado, no existen evidencias claras de que las exhumaciones de una misma fase se hayan llevado a cabo en un solo evento. Las diferencias en la profundidad de las matrices de las tumbas indican que no hay un nivel marcado o estándar para cada fase. Por otra parte, se observa que los individuos no han sido enterrados superponiéndose en la misma matriz, salvo en los casos de las tumbas E35 y E126, que se encuentran superpuestas pero respetando cada una su propia matriz. Esto sugiere que existió un respeto y un orden al momento de elaborar las matrices; es decir, que hubo una organización en la distribución de los diferentes enterramientos.

Con respecto a la profundidad de las matrices, esta es muy relativa y se ajusta al tamaño del cuerpo exhumado: poco profundas para el caso de infantes y niños, al contrario del caso de jóvenes y adultos. Sin embargo, hay excepciones como la tumba E56 cuyo pozo tiene $1,7 \mathrm{~m}$ de hondura y contenía solo un infante.

Los individuos están asentados sobre la base de las matrices, con la parte dorsal del cuerpo orientada hacia el noreste $(68,2 \%)$, al norte $(27,3 \%)$ y al este $(4,5 \%)$. Se encontraron en posición sentada flexionada: el 68,2\% con las extremidades inferiores en posición de loto y el porcentaje restante con las piernas flexionadas y pegadas al cuerpo. La muestra analizada está constituida por 21 individuos de sexo indeterminado (infantes y niños), 16 varones y 15 mujeres (en un rango de edad entre adolescentes y adultos). Todos los individuos presentan como indicador social la deformación craneana tabular erecta planolámbdica y tabular erecta plano-frontal (Mejía 2014). Ello sugiere que se trataría de un mismo grupo corporativo que fue mantenido por los chimús como una unicidad étnica.

En cuanto a las ofrendas de cerámica, estas se asociaron de manera directa o indirecta al individuo. Es importante señalar que el $27,5 \%$ presentaba una sola vasija como ofrenda; el 23,5\%, dos; el 11,8\%, tres; el $21,6 \%$, cuatro y el $15,7 \%$ cinco o más. Esta comparación es válida para las tres primeras fases. En tanto, las figurinas fueron identificadas en tres contextos (E100, E40 y E119), de la misma manera con los instrumentos de producción (E58, E7, y E112). Los ornamentos fueron registrados en siete tumbas (E27, E4, E6, E7, E13, E52); salvo el único colgante del E27 (Chimú Temprano), todos ellos estuvieron vinculados a la fase Media.

Los ajuares funerarios de las tumbas contenían otros tipos de ofrendas que no forman parte de este estudio, como por ejemplo los objetos metálicos hallados en 43 casos $(82,7 \%)$. La gran mayoría de los objetos trabajados son cuentas y colgantes hechos de malacológico (1387 elementos), óseo (30 objetos) y piedra (437 unidades). Entre los objetos de madera se han registrado husos, restos de mates, petates, costureros y ramas sin manufactura.

En gran parte, el ajuar funerario está relacionado con la actividad artesanal de la textilería, por lo que es posible que muchos de estos personajes hayan sido hilanderos y/o tejedores. Además, en los análisis de bioantropología se determinó que estos presentaban deformaciones o cambios degenerativos (osteofitosis degenerativa) en la columna vertebral, posiblemente producidos por el trabajo en el telar de cintura.

Las ofrendas de animales asociadas dentro de la matriz de las tumbas se limitan a Lama sp. "camélido doméstico", Cavia porcellus "cuy", Canis familiaris "perro doméstico" y Odocoileus virginianus "venado cola blanca". Sin embargo, se registraron de manera independiente más ofrendas en pozos menores que contenían un mayor número de individuos (principalmente de camélidos tiernos). Estos han sido estudiados a nivel isotópico y han permitido determinar que fueron criados en áreas bajas y cálidas, y no en áreas alto-andinas (Floreano 2016).

Estos datos corresponden al bagaje cultural recuperado en las diversas exhumaciones, que aún son muy generales y merecen mayores análisis. Al respecto, en el siguiente acápite se pretende dar un primer paso en cuanto a la tipología y seriación de la cerámica. 


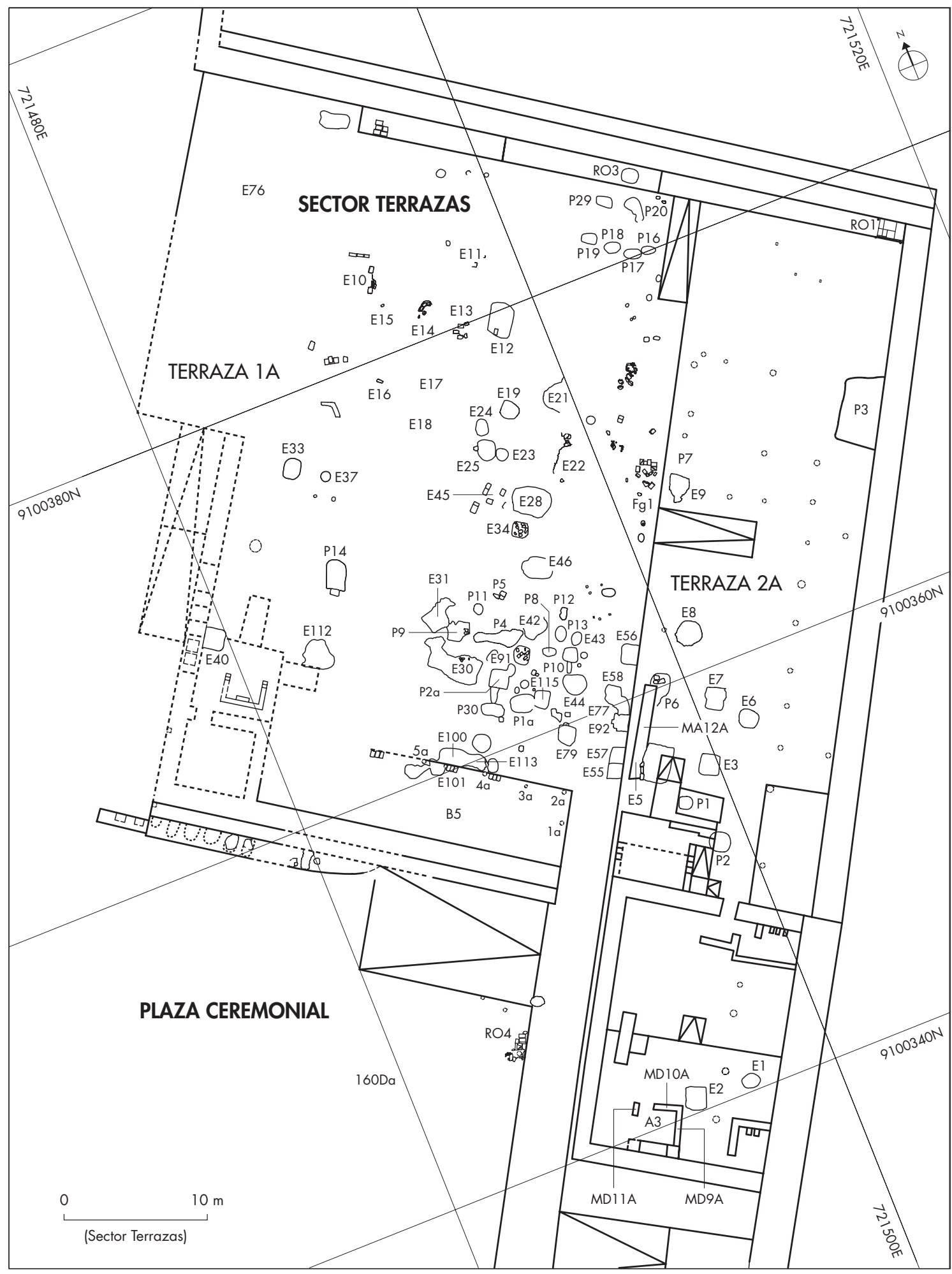

Figura 3. Plano de planta del primer y segundo nivel de tumbas del cementerio chimú. Figure 3. Map of levels 1 and 2 of the Chimu cemetery tombs. 


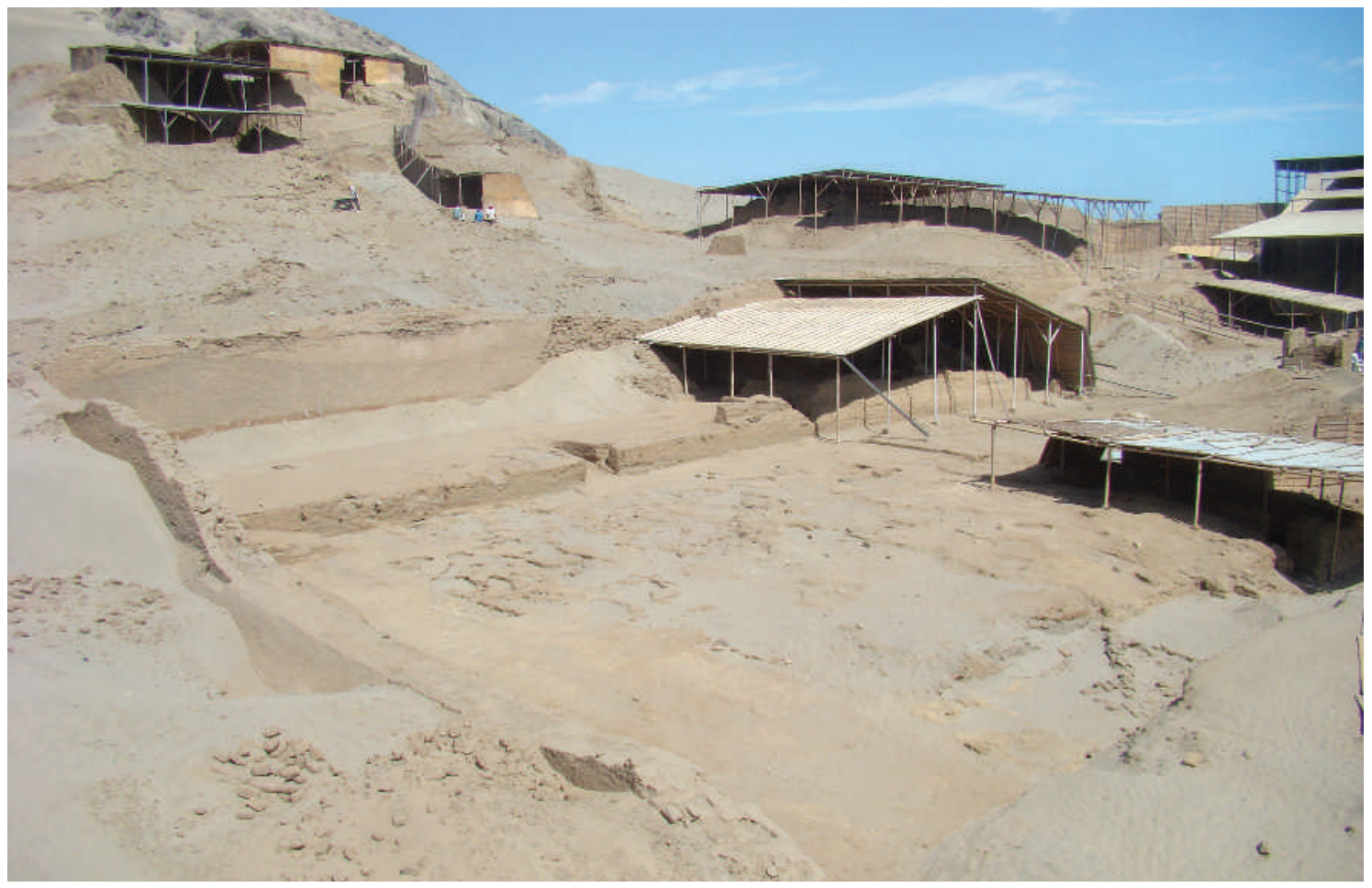

Figura 4. Vista desde el noroeste del cementerio chimú de Huaca de la Luna. Figure 4. View of the Chimu cemetery in Huaca de la Luna, facing northwest.

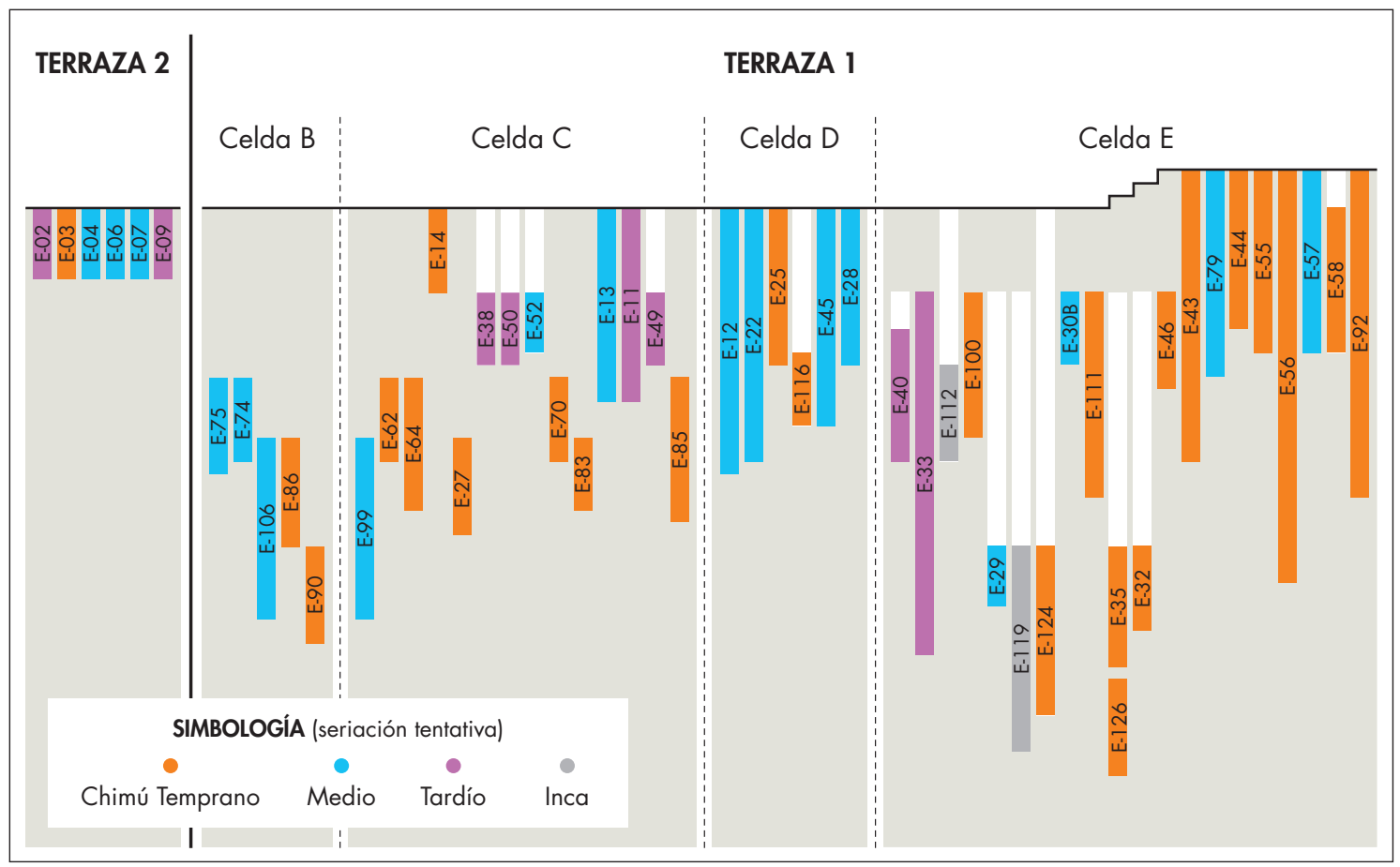

Figura 5. Matriz de las tumbas ubicadas en las diferentes celdas de relleno. Figure 5. Set of tombs as placed in their respective fillings cells. 


\section{TIPOLOGÍA DE LA CERÁMICA}

La tipología ha sido elaborada a partir de una muestra de 52 tumbas recuperadas en las diversas excavaciones del cementerio chimú de Huaca de la Luna. El análisis consistió en agrupar la muestra en cuatro grupos morfológicos: vasijas, figurinas, instrumentos de producción y ornamentos (tabla 1 y fig. 6). Los ornamentos constituyen el grupo más abundante, formado por 1938 elementos (92,3\% de la muestra), seguido por las vasijas, con 151 elementos $(7,2 \%) y$, en proporciones mucho menores, las figurinas $(0,3 \%)$ y los instrumentos de producción $(0,2 \%)$.

\section{Las vasijas}

Las formas de vasijas que se han tipificado son: botellas, cántaros, ollas, platos, escudillas, cuencos y vasos. Con respecto a su cocción, el 64,9\% (98 elementos) de la muestra corresponde a vasijas de horno cerrado con atmósfera reducida y el 35,1\% (53 elementos) a horno abierto con atmósfera oxidante. Existen casos, como las ollas, que parecieran ser de cocción mixta, producto de la exposición al fuego postcocción; sin embargo, debido a su condición, no se puede asegurar esta posibilidad.

La mayor parte de los objetos analizados presentan decoración mixta, por tanto se ha intentado agruparlos considerando la decoración más predominante. De esta manera, el 26,5\% de la muestra corresponde a vasijas sin decoración (40 elementos), mientras aquellas con decoración pictórica y estampado impreso (piel de ganso) están representadas con el 22,5\% y 21,9\% (34 y 32 elementos, respectivamente). En la categoría "otros", equivalente al $29,1 \%$ y donde se aprecian vasijas con decoración excisa, acanaladura, perforación, paleteado, escultórica, aplicaciones, etcétera, el tratamiento de la superficie es generalmente pulido, alisado y restregado, es decir, mixto. Finalmente, todas las piezas muestran evidencias de haber sido manufacturadas en moldes.

\section{Botellas}

Se trata de recipientes cerrados que presentan uno o dos golletes, generalmente altos y angostos, de forma tubular o cónica, representados por un total de 24 elementos (15,9\% de vasijas). Se dividen en tres subtipos:

Botellas de asa estribo. Vasijas cerradas de cuello alto compuesto por una agarradera en forma de arco o estribo en vertical (fig. 7 a-e). Generalmente, su cuerpo es de forma globular y su base plana. La muestra está constituida por 5 objetos que representan el 3,3\%.

Botellas de asa puente. Vasijas cerradas y con una agarradera que une dos golletes cónicos por medio de un asa cintada que funciona como puente (fig. $7 \mathrm{f}-\mathrm{h}$ ). Algunos ejemplares lucen un solo gollete unido a una figura ornitomorfa (fig. 7i); así también, otros son objetos de doble cuerpo que están unidos por la zona media y por un asa puente (fig. 7j). Su cuerpo suele ser de forma globular, paralelepípeda o carenada; las bases son planas. La muestra está formada por 8 objetos que representan el 5,3\%.

Botellas de asa lateral cintada. Vasija cerrada compuesta por una agarradera lateral que va desde el cuerpo hasta el gollete (fig. 7 k-o). Su cuerpo suele tener forma globular, carenada u ovoide, con base anular, convexa y plana. La muestra se compone de 11 elementos que representan el 7,3\%.

\section{Cántaros}

Se caracterizan por su gran tamaño, boca estrecha y gollete largo o corto. Sus cuerpos son anchos en la parte media, donde suelen llevar asas, y se estrechan en la base. Estas piezas se habrían utilizado para almacenar, transportar o servir líquidos, como chicha o agua. La muestra incluye 70 cántaros que representan el 46,4\% y se subdividen en los siguientes subtipos:

Cántaros de cuello convexo. Vasijas cerradas que presentan un engrosamiento hacia fuera del labio. Algunas piezas exhiben agarraderas tipo anillo entre la unión del cuello y el cuerpo, de forma simple o con motivo antropomorfo (fig. 8 a-c). Por lo general, su cuerpo es de forma globular, carenada u ovoide, con base convexa. La muestra se compone de 8 elementos que representan el 5,3\%.

Cántaros de cuello expandido. Vasijas cerradas y de labio redondeado, algunas de las cuales poseen agarraderas y cara gollete (fig. $8 \mathrm{~d}$-f). Su cuerpo suele ser de forma globular, carenada u ovoide; su base, convexa. La muestra está constituida por 9 elementos que equivalen al $6 \%$.

Cántaros de cuello evertido. Vasijas cerradas y de labio redondeado, algunas de las cuales poseen asas laterales ubicadas en el gollete (fig. 8 g-i). En general, su cuerpo es de forma globular o barril, con base convexa. La muestra consta de 40 elementos que representan el $26,5 \%$. 
Tabla 1. Análisis de la cerámica recuperada en el cementerio chimú de Huaca de la Luna. Table 1. Analysis of ceramic pieces recovered from the Chimu cemetery of Huaca de la Luna.

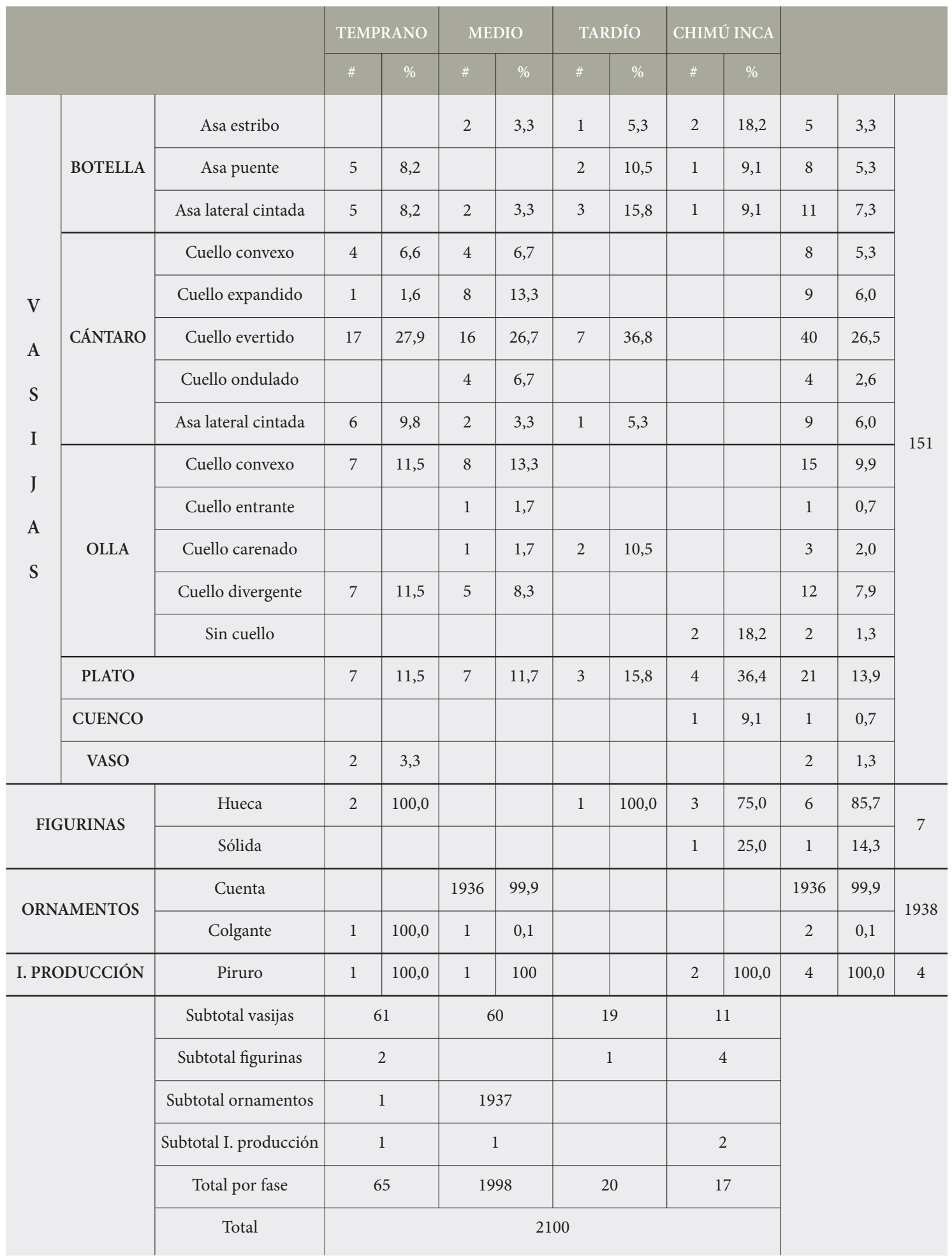




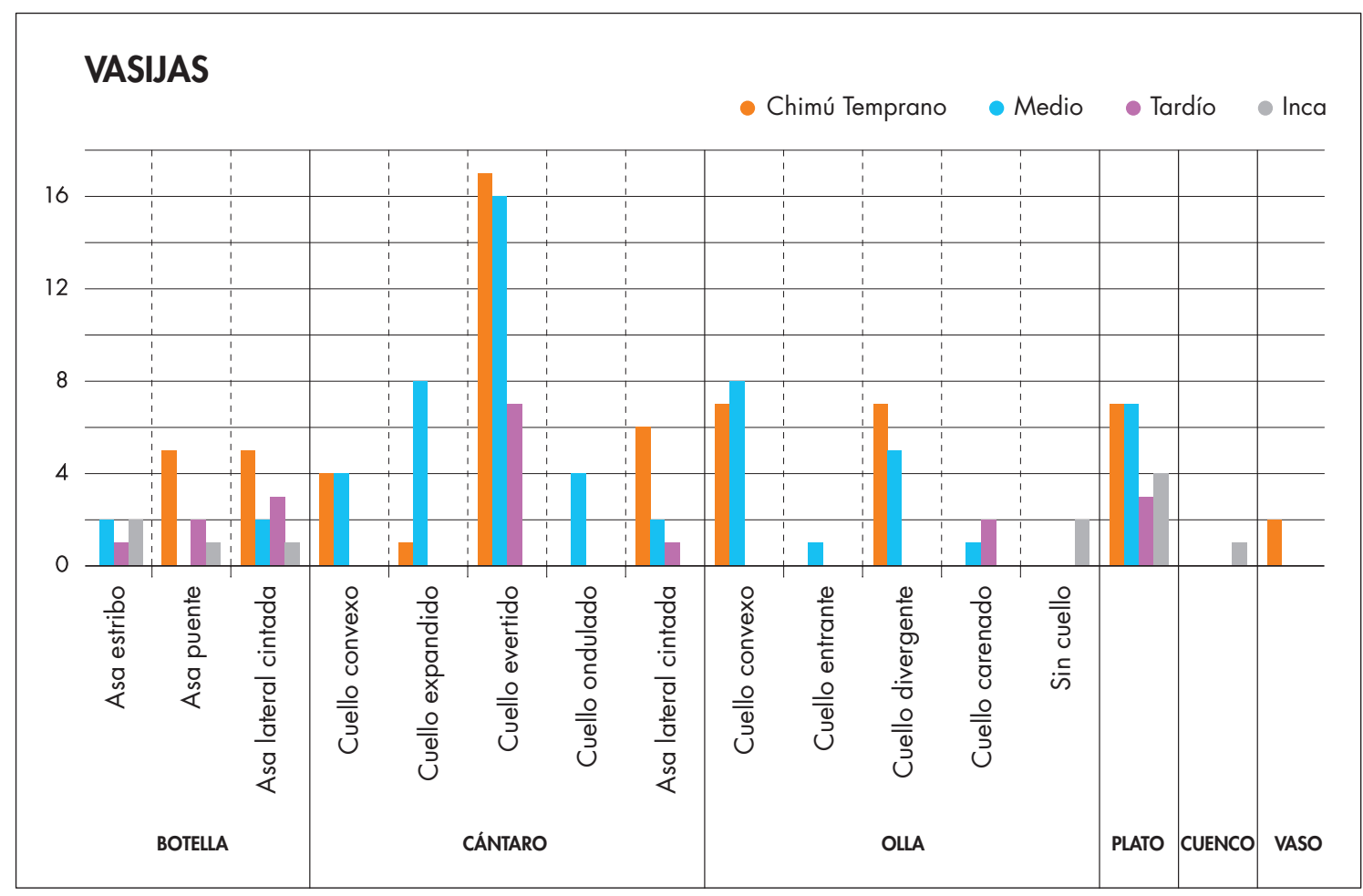

Figura 6. Distribución de los tipos de vasijas según fases. Figure 6. Distribution of vessel types by phase.

Cántaros de cuello ondulado. Vasijas cerradas que presentan una curvatura en la parte del gollete (fig. 8j). Algunas piezas poseen dos asas laterales ubicadas entre el gollete y el hombro de la vasija. Su cuerpo generalmente es de forma globular u ovoide, con base convexa. La muestra contiene 4 elementos que representan el 2,6\%.

Cántaros de asa lateral cintada. Vasijas cerradas y con asas laterales cintadas que van desde el cuerpo de la pieza hasta el gollete (Fig. $8 \mathrm{k}-\mathrm{n}$ ). Su cuerpo es de forma globular u ovoide y presenta base convexa o plana. La muestra está constituida por 9 elementos que representan el 6\%.

\section{Ollas}

Se caracterizan por tener una boca ancha y un cuerpo generalmente esférico. Su función está directamente asociada a la cocción de alimentos. También tenían un uso ritual, ya que eran depositadas junto al difunto en su tumba. La muestra está formada por 33 ollas que representan el $21,9 \%$. Estas vasijas se subdividen en los siguientes subtipos:
Ollas de cuello convexo. Vasijas abiertas y con el borde del labio redondeado. El diámetro de abertura de la boca es variado (fig. 9 a-c). Algunas piezas presentan agarraderas tipo anillo que se ubican en el cuello de la vasija. Su cuerpo es de forma globular, carenada u ovoide, con base convexa. La muestra corresponde a 15 elementos que representan el 9,9\%.

Ollas de cuello entrante. Vasijas abiertas y con el labio inclinado hacia dentro (fig. 9d). Su cuerpo es de forma globular y su base convexa. La muestra es integrada por 1 elemento que representa el $0,7 \%$.

Ollas de cuello carenado. Vasijas abiertas que cuentan con una carena (ondulación) en el cuello. Su cuerpo es de forma globular u ovoide, con base convexa (fig. 9 e-f). La muestra se compone de 3 elementos que representan el $2 \%$.

Ollas de cuello divergente. Vasijas abiertas de labio redondeado, compuesto por una agarradera tipo anillo que va desde el cuello hasta el gollete de la pieza (fig. 9 $\mathrm{g}$-i). Su cuerpo es de forma globular, carenada u ovoide; su base, convexa. La muestra corresponde a 12 elementos que representan el 7,9\%. 


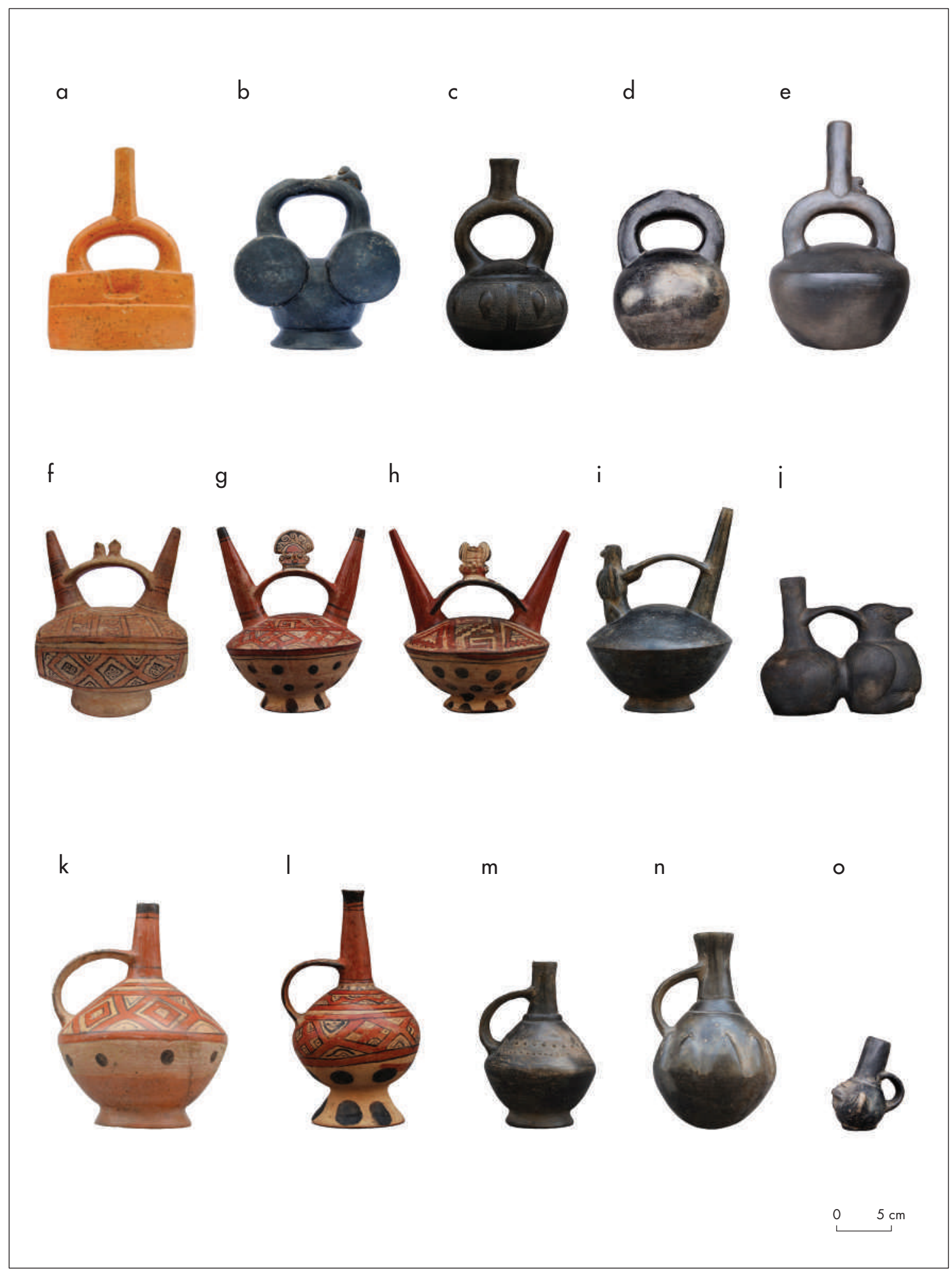

Figura 7. Botellas: $\mathbf{a}-\mathbf{e})$ asa estribo; $\mathbf{f}-\mathbf{j}$ ) asa puente; k-o) asa lateral cintada. Figure 7. Bottle types: $\boldsymbol{a}-\boldsymbol{e})$ stirrup handle; $\boldsymbol{f}$-j) bridge handle; $\boldsymbol{k}$-o) side handle with waist. 
$a$

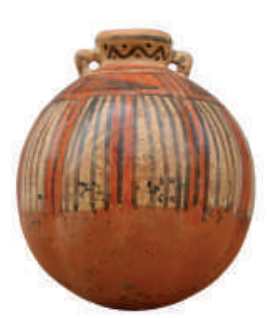

d

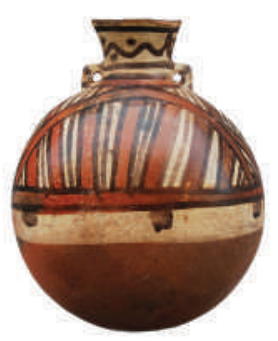

g
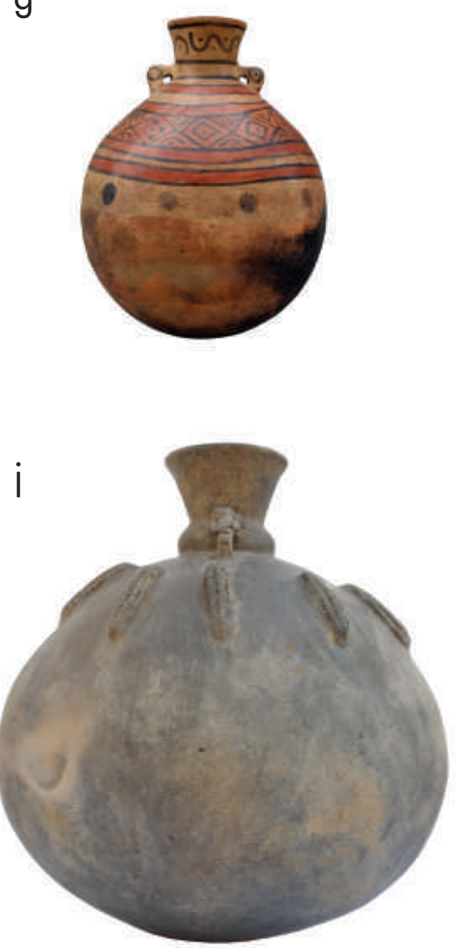

b

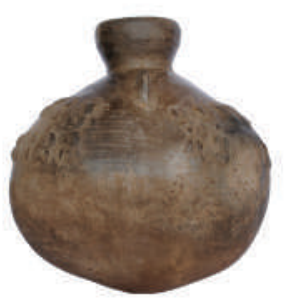

e

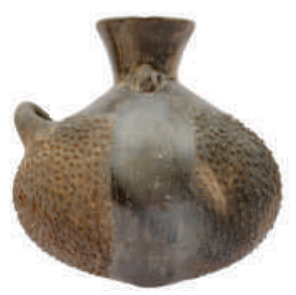

h

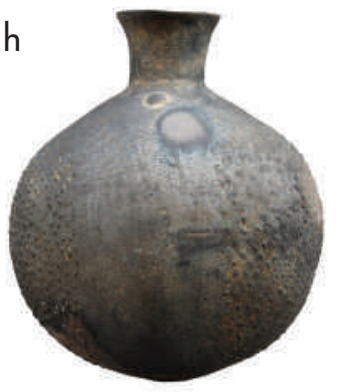

k
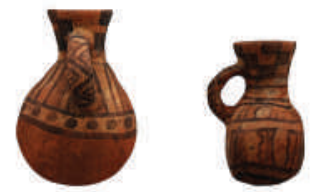

C

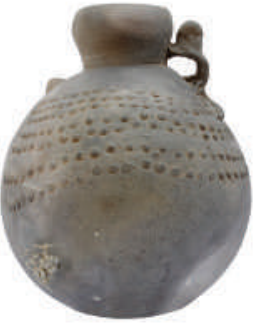

f

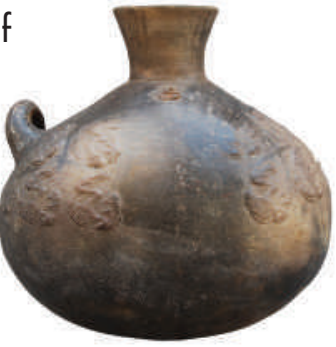

i

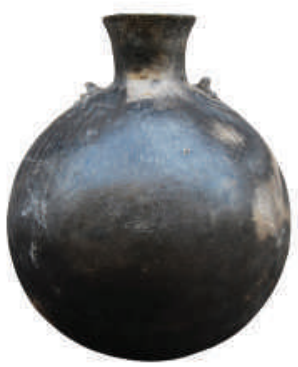

$\mathrm{m}$

n
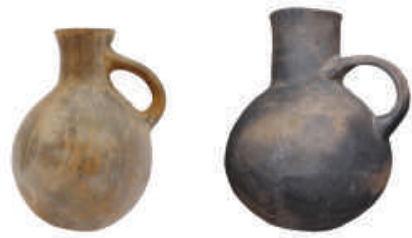

Figura 8. Cántaros: a-c) de cuello convexo; d-f) de cuello expandido; g-i) de cuello evertido; j) de cuello ondulado; k-n) asa lateral cintada. Figure 8. Pitchers: $a-c)$ convex neck; $d$-f) flared neck; $g-i)$ everted neck; $j$ ) wavy neck; $k$-n) lateral handle with waist. 


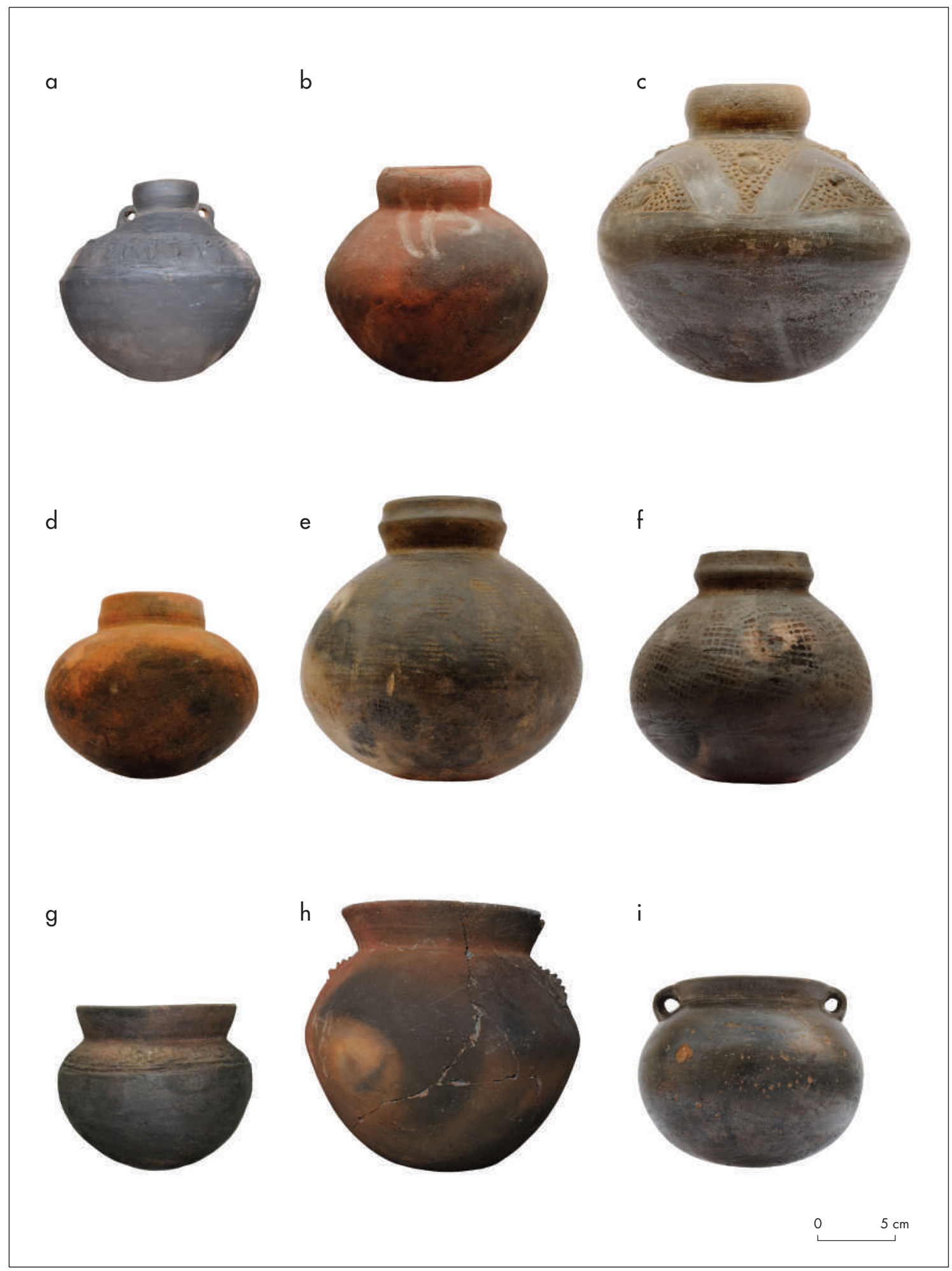

Figura 9. Ollas: a-c) de cuello convexo; d) de cuello entrante; e-f) de cuello carenado; g-i) de cuello divergente. Figure 9. Pots: a-c) convex neck; d) neck with inward-sloping lip; $e$-f) carinated neck; $g$-i) flared neck. 
a

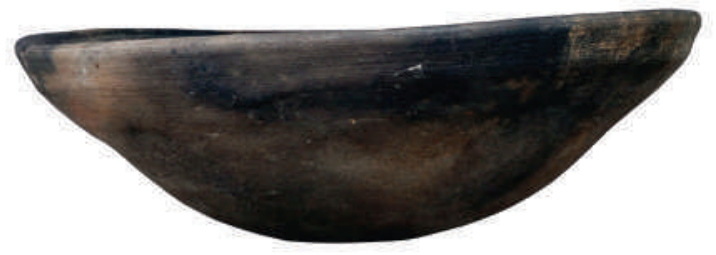

C

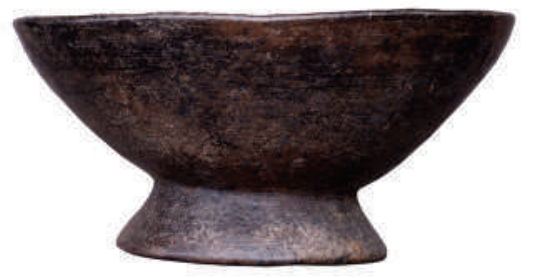

d

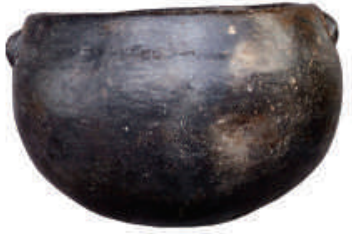

b

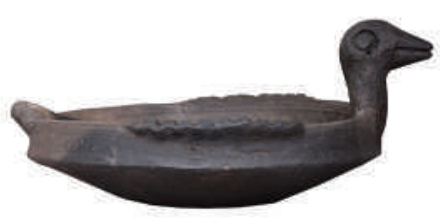

e

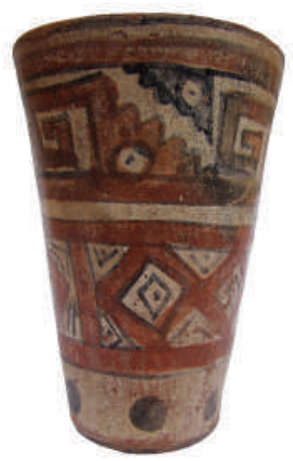

0

Figura 10: a-c) platos; d) cuenco; e) vaso. Figure 10: a-c) serving dishes; d) bowl; e) cup.

Ollas sin cuello. Vasijas abiertas que no tienen cuello y cuentan con dos asas laterales (fig. 17d). Su cuerpo es de forma globular, carenada u ovoide y su base convexa. La muestra suma 2 elementos que representan el $1,3 \%$.

\section{Platos}

Se caracterizan por ser vasijas abiertas cuya abertura es mayor que su altura, al punto que varias piezas tienden a ser casi totalmente planas o con una pequeña concavidad en medio y un borde plano (fig. $10 \mathrm{a}-\mathrm{c}$ ). La muestra es del tipo expandido, el borde suele ser más delgado que el cuerpo. Está compuesta de 21 elementos que representan el 13,9\%.

\section{Cuencos}

Se distinguen por ser recipientes hondos y anchos que carecen de borde. La altura tiende a ser siempre menor que el ancho o diámetro y su cuerpo es de forma semiesférica (fig. 10d). Su uso está directamente asociado a la cocción de alimentos y a la esfera ritualfuneraria. La muestra es integrada por 1 elemento que representa el $0,7 \%$.

\section{Vasos}

Se caracterizan por ser recipientes abiertos cuya altura es siempre mayor que el ancho o diámetro de la boca. El cuerpo es de forma cilíndrica y su base plana. Además de servir para beber líquidos, se utilizan en contextos ritual-funerarios (fig. 10e). La muestra está formada por 2 elementos que representan el 1,3\%. 


\section{Figurinas}

Se trata de esculturas antropomorfas elaboradas de arcilla cuya manufactura se realizó mediante el modelado y moldeado. La función de estos objetos estuvo relacionada con un carácter ritual. La mayor parte de ellas $(85,7 \%)$ fue cocida en horno cerrado de atmósfera reducida, mientras que una sola $(14,3 \%)$ es de cocción mixta. Todas las piezas muestran un tratamiento pulido y solo en las figurinas recuperadas de la tumba E119 hay evidencias de decoración pictórica en los rostros (fig. 11). Los resultados obtenidos con analizadores XRF portátiles determinaron que el color rojizo aplicado en casi todo el rostro corresponde a sulfuro de mercurio (cinabrio), y el color verde entre la boca y el mentón a óxido cúprico. La muestra total suma 7 elementos ( $0,3 \%$ de la muestra) que se subdividen en dos subtipos:

Figurinas huecas. Esculturas vacías que representan a personajes femeninos. Están elaboradas sobre la base de molde, resaltan los senos y una caladura entre las piernas para poder distinguir su órgano sexual (figs. $14 \mathrm{k}, 16 \mathrm{~h}$ y $18 \mathrm{~g}$ ). La muestra consta de 6 elementos que representan el 85,7\%.

Figurinas sólidas. Esculturas compactas de representación femenina elaboradas sobre la base del moldeado (fig. 17h). La muestra corresponde a 1 elemento que representa el 14,3\%.

\section{Ornamentos}

En este grupo se encuentran las cuentas y colgantes que han sido utilizados como ornamentos corporales (manos, cuellos, orejas). Estos objetos connotaban prestigio y estatus, y debieron ser empleados en vida por los difuntos. Carecen de decoración, salvo algunos casos con pequeñas incisiones en ambos subtipos. Estos presentan un tratamiento alisado o pulido sin mayores variantes.

Las cuentas presentan un orificio en la parte central que sirve para engarzar un collar o brazalete (fig. 12a), y sus formas son diversas: esférica, tubular, discoidal, rectangular, etc. La muestra corresponde a 1936 elementos de cocción reductora, que representan el 99,9\%. Por otro lado, los colgantes exhiben un orificio en la parte superior de la pieza que servía para engarzar el hilo (fig. 12b). La muestra está constituida por 2 objetos de cocción oxidante, equivalentes al $0,1 \%$ de la muestra.

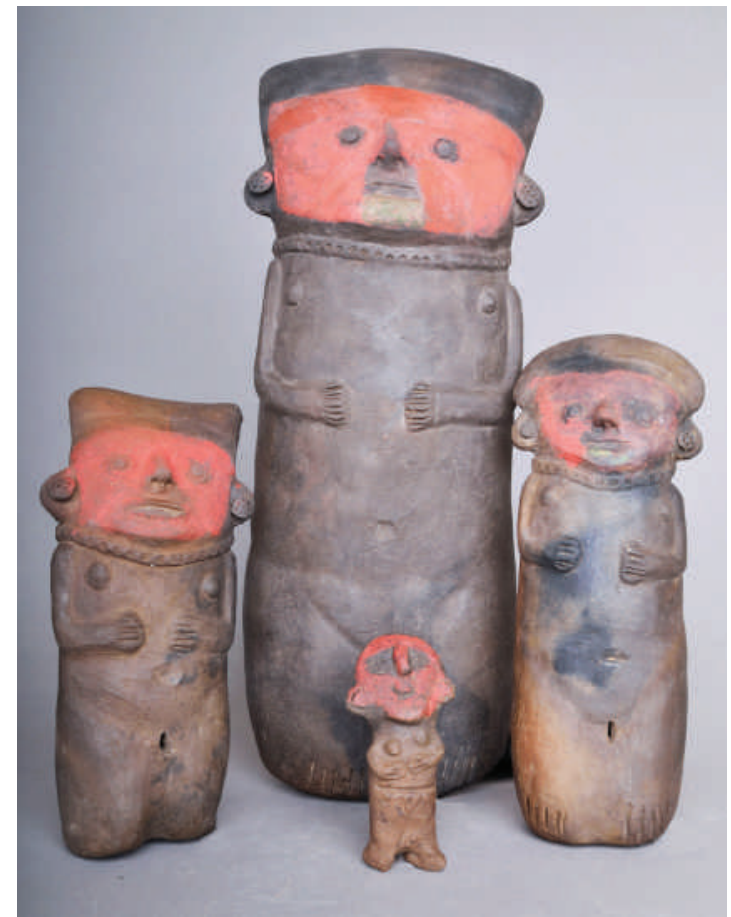

Figura 11. Figurinas huecas y sólidas recuperadas en la tumba E119. Figure 11. Hollow and solid figurines recovered from tomb E119.

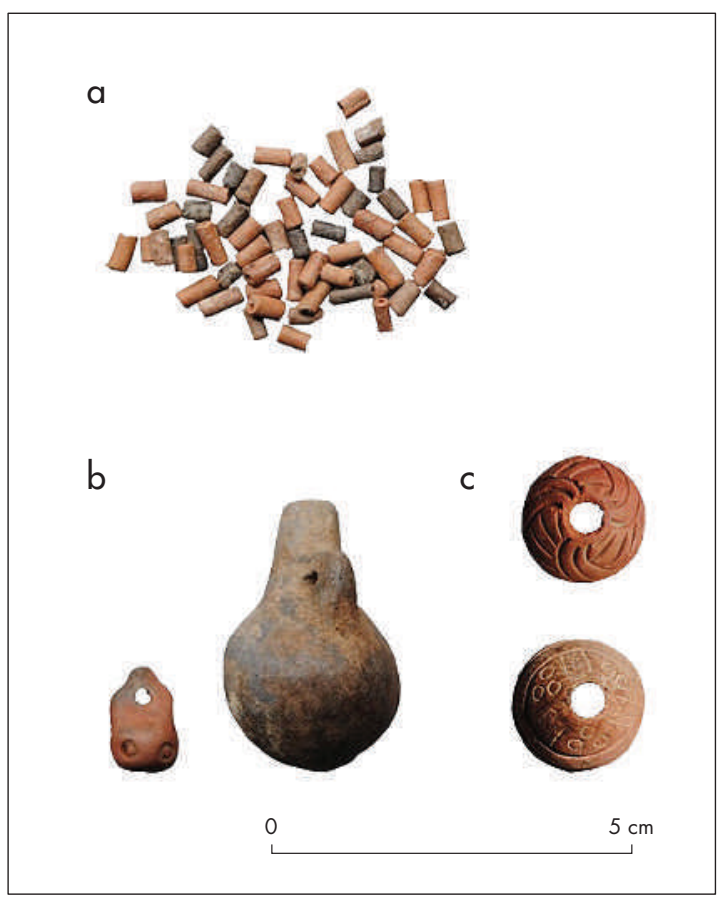

Figura 12. Ornamentos e instrumentos de producción. Figure 12. Ornaments and productive implements. 


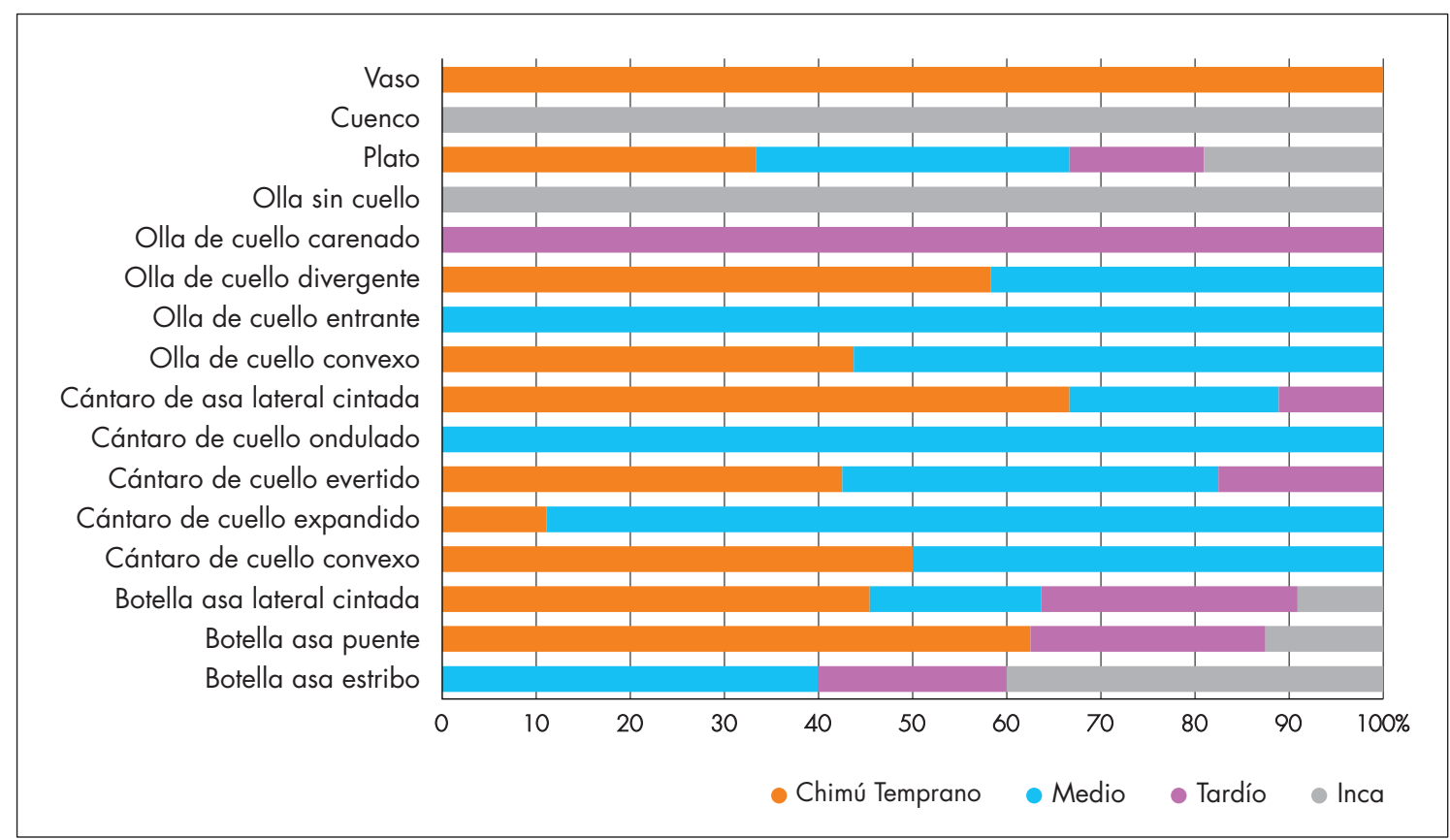

Figura 13. Distribución de la cerámica según la seriación. Figure 13. Distribution of ceramics according to seriation.

\section{Instrumentos de producción}

Los instrumentos de producción registrados en el cementerio están elaborados específicamente para la producción artesanal, como por ejemplo piruros que se utilizaban para el hilado de prendas. Los piruros suelen presentar una perforación en el centro, por donde se coloca el huso para facilitar el movimiento rotatorio en la elaboración del hilo. La muestra está compuesta por 4 elementos de cocción oxidante que ostentan incisiones de diversas formas y se encuentran alisados o pulidos, sin mayores variantes (fig. 12c).

\section{SERIACIÓN}

Como se ha señalado, este trabajo tiene como soporte la propuesta tentativa de cronología relativa planteada a finales de los años setenta (Donnan \& Mackey 1978), la que no ha sido corroborada o replanteada desde entonces. Ante la evidente ausencia de propuestas tipológicas y cronológicas con fechados radiocarbónicos, este artículo se ve limitado a continuar con la propuesta antecesora. Para ello, considera las vasijas como la muestra principal del análisis (fig. 13).
Al comparar las cuatro fases, se observan formas que aparecen y desaparecen. Es importante destacar que en la muestra no se cuenta con vasijas que hayan sido descubiertas en otros contextos chimú, especialmente de uso doméstico, como escudillas, paicas o ralladores (Prieto 2008); además, es posible que algunas formas existentes no hayan sido registradas en la muestra por tratarse de entornos netamente funerarios y por la reducción paulatina de estos entre cada fase. Otro dato importante es la cocción de las vasijas: su presencia en horno abierto con atmósfera oxidante se observa solo en las primeras dos fases, ya que luego se estandarizó el uso de vasijas de cocción reductora.

\section{Chimú Temprano}

La muestra estudiada corresponde a 61 vasijas provenientes de un total de 25 tumbas primarias, salvo las tumbas E14 y E100 que presentaban indicios de manipulación postentierro. El 63,9\% de las piezas son de horno abierto con atmósfera oxidante y el $36,1 \%$ de horno cerrado con atmósfera reductora. Su decoración se caracteriza por ser pictórica $(49,2 \%)$, en su mayoría tricolor (rojo-ocre, blanco-crema y negro) y en menor proporción bicolor (blanco-crema y negro) y mono- 
croma (blanco-crema). El 24,6\% de las vasijas no posee decoración alguna, mientras que el $18 \%$ muestra otro tipo de decoración, como estampado impreso, muescas, perforaciones o aplicaciones. Finalmente, el 8,2\% restante exhibe decoración piel de ganso.

Con respecto a los tipos, existe mucha variabilidad de formas propias de esta fase y otras que aparecen en la siguiente. La botella asa estribo es una forma inexistente, sin embargo, las botellas asa puente (fig. 14a) y asa lateral cintada cuentan con 5 objetos cada una (fig. 14b). Entre los 5 subtipos de cántaros, solo el cántaro de cuello ondulado se halla ausente; por su parte, el evertido es el más representativo (fig. 14e), seguido por el de asa lateral cintada (fig. 14f), el convexo (fig. 14c) y el expandido (fig. 14d). En el caso de las ollas, se observan dos formas: divergente y convexa (fig. 14g y 14h). Los platos son una forma común en las cuatro fases; sin embargo, solo en esta existe un conjunto de platos con soporte anular (fig. 14i). Por último, en esta fase se han registrado también los únicos vasos tipo kero (fig. 14j).

\section{Chimú Medio}

La fase Media es la menos estudiada - hasta la fecha- por los investigadores. En este caso, la muestra corresponde a un lote de 60 vasijas provenientes de 18 tumbas. Solo las tumbas E99 y E106 presentaron evidencias de manipulación postentierro. La cocción de las vasijas aumenta al $78,3 \%$ de la muestra con horno cerrado de atmósfera reductora; el $21,7 \%$ restante corresponde al horno abierto con atmósfera oxidante. La decoración pictórica se reduce considerablemente con respeto a la fase anterior, limitándose al 6,7\%. La decoración de vasijas con piel de ganso aumenta al 33,3\%, seguido por las vasijas sin decoración $(31,7 \%)$ y otros $(28,3 \%)$.

Por razones desconocidas, entre las vasijas no se han consignado las botellas de asa puente. Con todo, la botella de asa estribo (fig. 15a) aparece junto a la de asa lateral, que ya es común desde la fase anterior (fig. 15b). Tanto para los cántaros como para las ollas se observan nuevos subtipos que serían propios de esta fase: el cántaro de cuello ondulado (fig. 15f) y las ollas de cuello entrante (fig. 15i) y de cuello carenado (fig. 15k). Por su parte, se mantienen los otros subtipos de cántaros: el evertido es el más común, seguido por el expandido, el convexo y el asa lateral cintada; y de ollas: hay de cuello convexo y divergente. Finalmente, la proporción de platos es igual de abundante que en la fase anterior.

\section{Chimú Tardío}

La cerámica ubicada en la tercera fase consta de 19 vasijas provenientes de 7 tumbas. Las tumbas E2, E38 y E40 muestran indicios de manipulación postentierro, pero fueron incluidas en la muestra por la importancia de los objetos que contienen. Para esta fase, la cocción de las vasijas es en su totalidad de horno cerrado con atmósfera reductora. Respecto de la fase anterior, la decoración ha cambiado: los elementos decorados con piel de ganso se reducen al 16,7\% de la muestra, y aparecen tres vasijas con decoración paleteada (fig. 16g), la cual es una "técnica decorativa [...] casi exclusiva del momento más temprano del período Chimú Tardío, es decir el Chimú Tardío A y durante el período Lambayeque" (Prieto 2008: 126).

Las vasijas de esta fase carecen de muchas formas existentes para el período, debido al reducido tamaño de la muestra (con respecto a la fase anterior). Entre las botellas, se observan los tres subtipos, siendo el de asa lateral cintada el más común (fig. 16c). Entre los cántaros, predomina el tipo evertido (fig. 16d) y hay un solo elemento de asa lateral cintada (fig. 16e). La olla de cuello carenado fue la única registrada (fig. $16 \mathrm{f})$, mientras que, al igual que en las fases anteriores, la presencia de platos es indiscutible. Entre ellos, destaca uno con soporte pedestal que se asemeja a una copa (fig. 16g).

\section{Chimú-Inca}

La cerámica de esta última fase es muy reducida: 11 vasijas provenientes de 2 tumbas. La tumba E119 presenta evidencias de manipulación postentierro, pero fue considerada en la muestra por la importancia de su ajuar cerámico. Al igual que en la fase anterior, la totalidad de las vasijas son de horno cerrado con atmósfera reductora. La decoración se caracteriza en su mayoría por aplicaciones diversas y no existe ningún tiesto con decoración piel de ganso.

Las formas analizadas son típicas de este período, como la botella asa estribo con el gollete biselado (fig. 17a), la olla sin cuello con agarraderas tipo anillo (fig. 17d) y los platos (fig. 17e); todas formas típicas cuzqueñas pero de manufactura local (Bauer 2001). Es relevante que la botella asa puente de doble cuerpo sea la única registrada en el total de la muestra (fig. 17b). La presencia de formas provenientes de la fase 
a

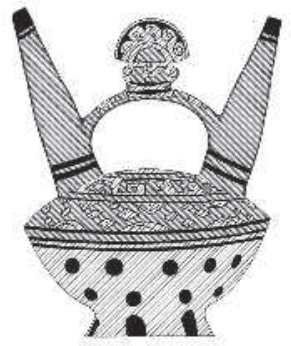

C

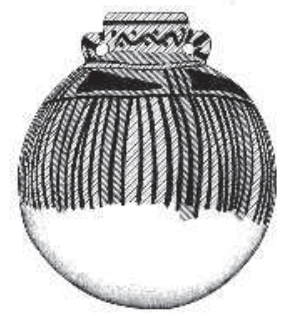

g

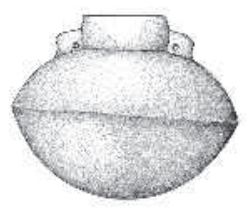

i

d

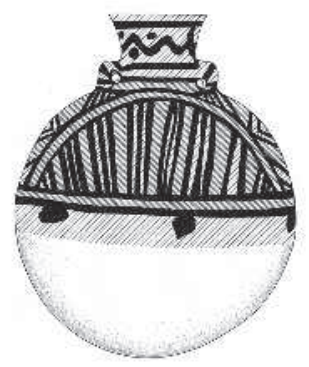

h

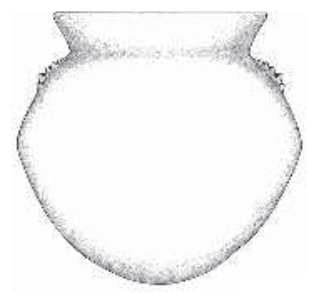

k b

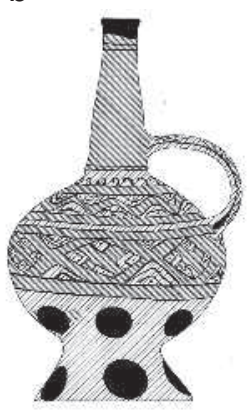

e

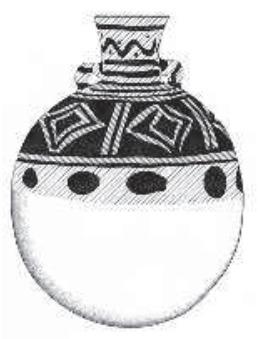

$f$

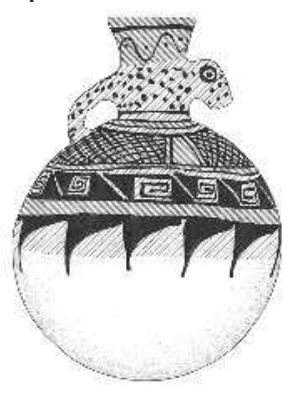

i
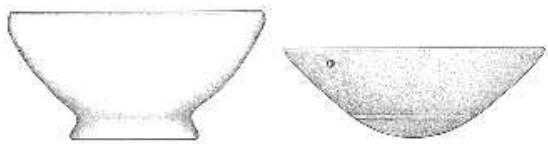

0 $10 \mathrm{~cm}$

Figura 14. Cerámica de la fase Chimú Temprano. Figure 14. Ceramics from the Early Chimu Period. 


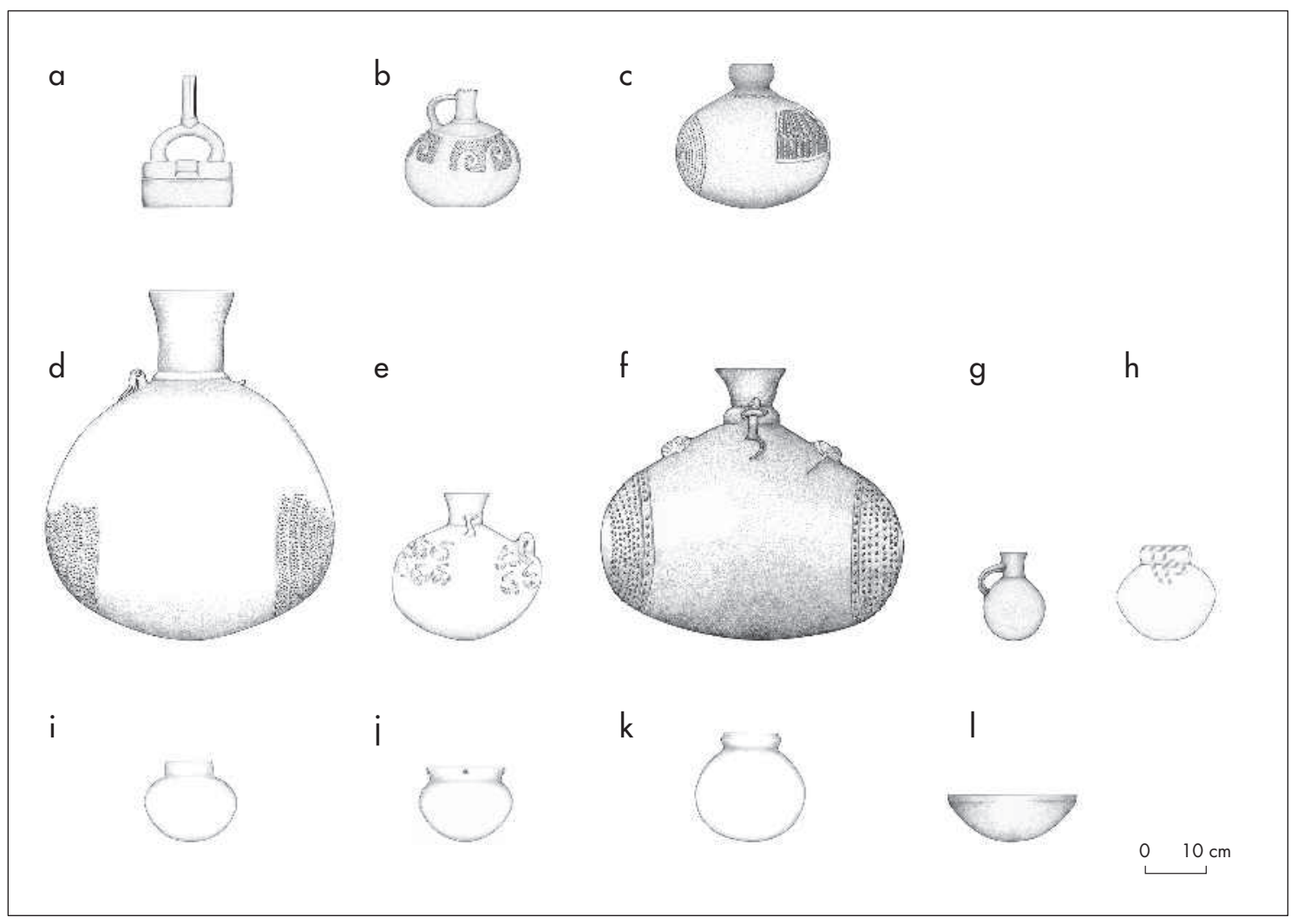

Figura 15. Cerámica de la fase Chimú Medio. Figure 15. Ceramics from the Middle Chimu Period.

Temprana, como la botella de asa lateral cintada (fig. 17c) y la aparición del único cuenco en toda la muestra (fig. 17f), expresa las limitaciones de la misma.

\section{COMENTARIOS}

La cerámica representa el indicador diagnóstico más importante durante el proceso de excavación de un yacimiento, pues su identificación y clasificación permite desarrollar un marco temporal y cronológico de las sociedades que la elaboraron en una determinada época, así como entender los atributos comunes de cada grupo (Clarke 1984). Si bien es cierto que en muchos casos la cerámica es empleada como un indicador de culturas o grupos étnicos debido a la homogeneidad de sus atributos tecnológicos, morfológicos y estilísticos, en otros casos puede generar confusiones o distorsiones al momento de dar una explicación histórica de las sociedades pasadas: "la homogeneidad de un patrón cerámico puede estar determinada por los modelos que una elite estatal impone en zonas sobre las cuales ejerce dominio" (Lumbreras 2005: 121). En este caso, el autor discute el empleo de la cerámica como indicador de expansión de entidades políticas; sin embargo, algunas entidades dentro de un mismo territorio pueden desarrollar variantes en la cerámica como una manera de expresar su propia identidad (Donnan 2011).

La autonomía de cada sociedad llevó al desarrollo de estilos únicos y variables a través del tiempo, como explican Renfrew y Bahn (1998: 110): "los productos de un período y lugar determinado tienen un estilo reconocible: debido a su forma y decoración distintas son, en cierto sentido, características de la sociedad que las creó [...] el cambio estilístico (de forma y decoración) de los artefactos suele ser bastante gradual y evolutivo". En efecto, los estilos no se transforman de manera brusca y desordenada, sino que sufren un cambio pausado que se acopla al proceso de adaptación de las sociedades que los adquieren. Los estilos, como "modas" en el tiempo 
a
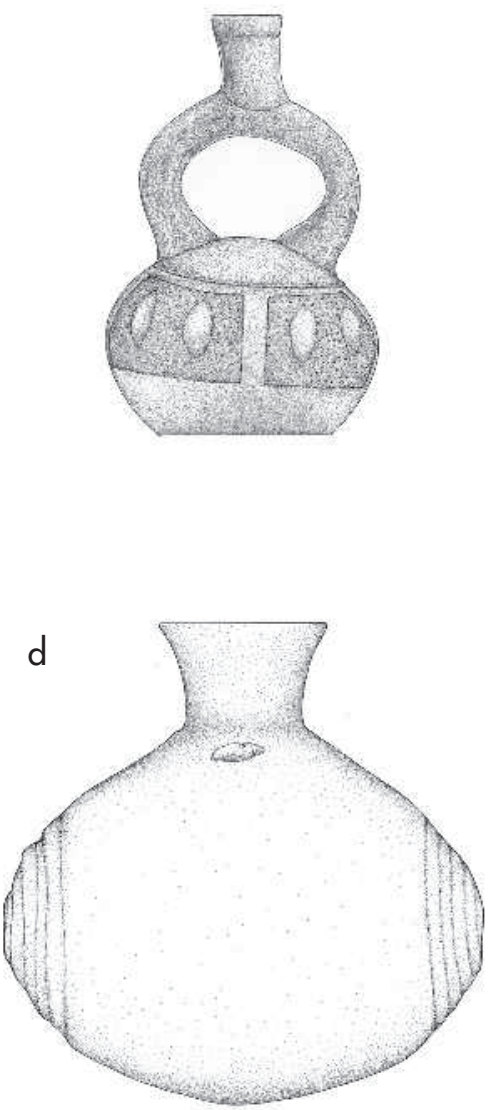

g

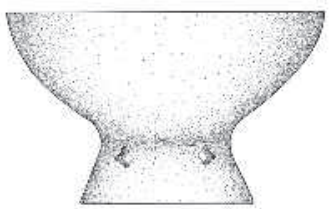

b

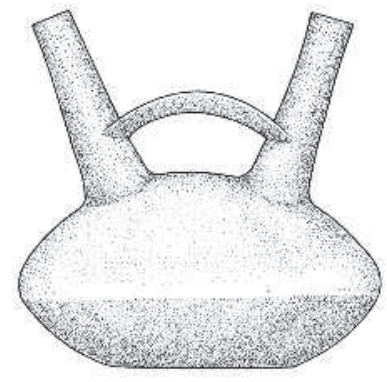

e

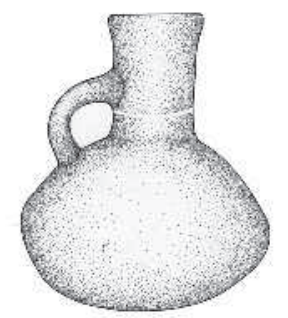

h

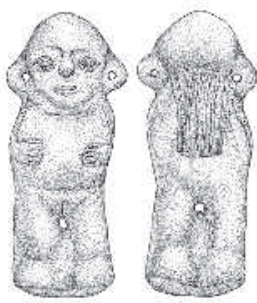

C

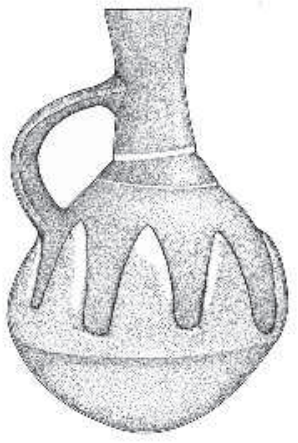

f

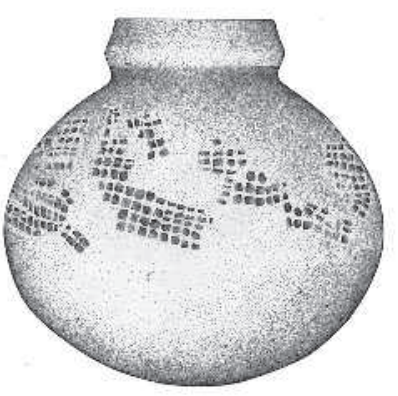




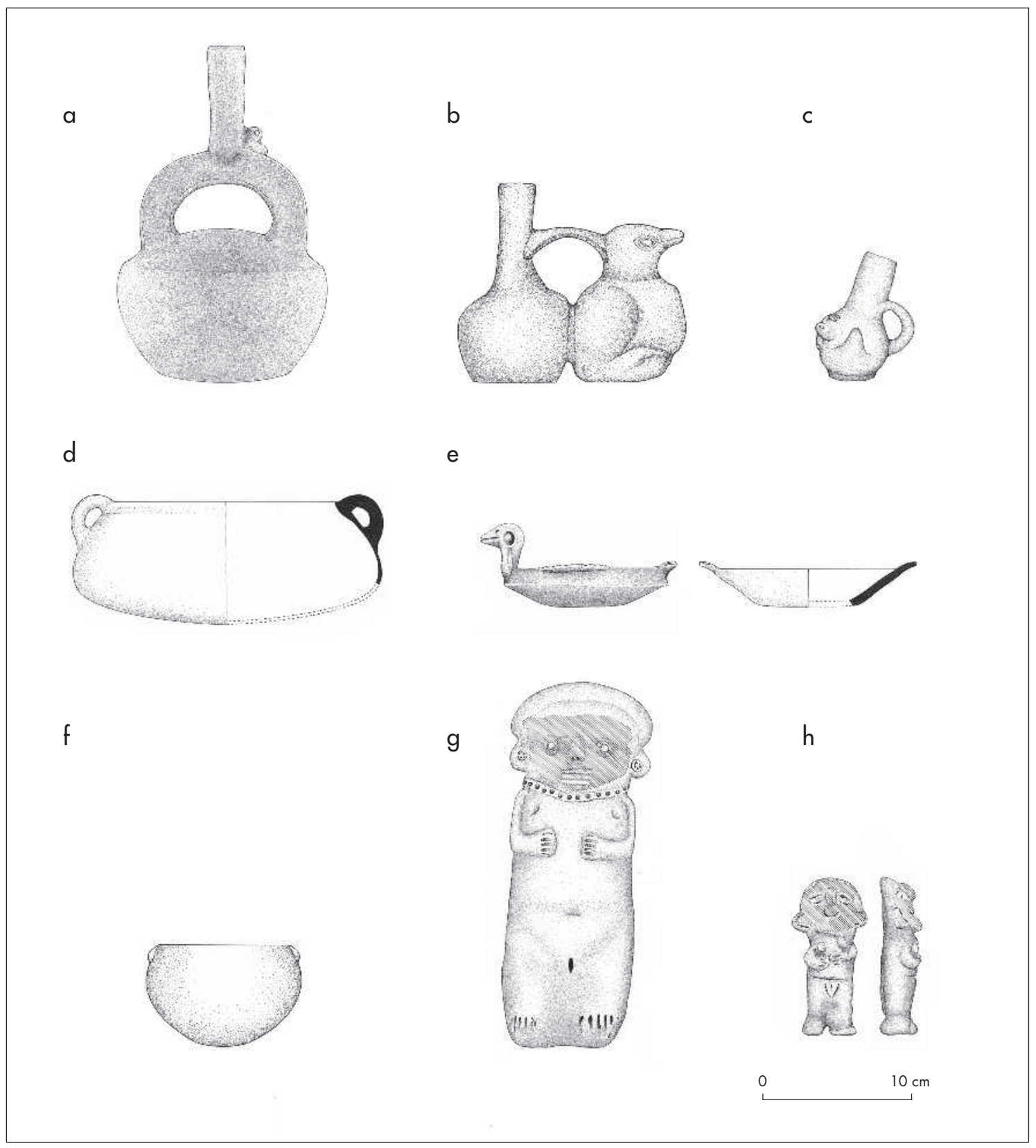

Figura 17. Cerámica de la fase Chimú-Inca. Figure 17. Ceramics from the Chimu-Inca Period.

y el espacio, pueden ser apreciados a través de la clasificación de las formas más representativas.

La clasificación tipológica de la cerámica parte de la observación visual a partir de la cual se elaboran conjeturas subjetivas e intuitivas para entender la funcionalidad que cumplía cada forma de cerámica. Esto conduce a largas discusiones sobre el uso y fun- ción que jugaban en las sociedades del pasado. Como señala Manrique (2001: 51), "el criterio de función no siempre está relacionado estrechamente con la forma misma; vasijas escultóricas pueden cumplir funciones utilitarias, votivas o ambas". La función está orientada a la finalidad para la cual la pieza fue creada, el interés del ser humano en ella. La dificultad para precisar esa 
función ha llevado a muchos investigadores a generar denominaciones relativas.

En muchas tumbas, tanto personajes de clase alta como baja se encuentran acompañados de vasijas cuya función era contener líquidos (p.e., botellas, cántaros, jarras o vasos), pero que por su asociación al difunto connotan un uso ritual (a manera de ofrenda). Este aspecto genera otro tipo de confusiones: se desconoce si las vasijas eran elaboradas exclusivamente como ofrenda para el difunto en su camino al mundo de los muertos o bien eran objetos usados en vida que debían permanecer a su lado para serles útiles en la vida no terrenal. En este trabajo no se han realizado estudios de desgaste en las vasijas, ni tampoco análisis arqueométricos de su contenido, los cuales deben formar parte de una futura investigación.

La cerámica Chimú se ha entendido como el resultado de un sincretismo cultural de diversos estilos provenientes del Horizonte Medio (Mackey 1985). Donnan y Mackey (1978) hicieron la primera propuesta de "seriación" a partir de un lote de tumbas en contexto y alteradas del valle de Moche. Los autores plantearon tentativamente que la fase Temprana debió existir entre el 800 y 1000 DC, la fase Media hasta el 1200, la Tardía hacia el 1470 (cuando tiene lugar la interrupción causada por la expansión del Tahuantinsuyu) y, finalmente, la fase Chimú-Inca, que se extiende hasta la llegada de los conquistadores hispanos en 1532. A continuación, debatiremos esta cronología desde las limitaciones contextuales con que se cuenta a la fecha.

\section{TANGUCHE, TOMAVAL Y ABIGARRADO. UN ENSAYO PARA COMPRENDER EL CHIMÚ TEMPRANO}

Las evidencias para discutir la fase Chimú Temprano están representadas por las 31 tumbas recuperadas de contextos disturbados del sitio Banderas y de contextos primarios de las Huacas de Moche (Donnan \& Mackey 1978). Asimismo, se cuenta con los recientes hallazgos obtenidos en las excavaciones del núcleo urbano Moche y las 25 tumbas correspondientes a la fase Temprana del cementerio chimú de Huaca de la Luna.

Mackey (1985) denomina Chimú 1 a la fase Temprana, pero en su muestra de análisis se aprecia una confusión de varios estilos. No solo existen piezas que pertenecen al estilo Cajamarca Costeño y Casma Local del valle de Jequetepeque (Castillo 2000, Rucabado \& Castillo 2003), sino que además, entre las vasijas "tricolores", se pueden determinar claramente hasta tres estilos distintos: Tanguche Temprano del valle de Santa (Wilson 1988, Bélisle 2008), Tomaval del valle de Virú (Ford \& Willey 1949) y Abigarrado de Chan Chan (Larco 1938). Estas diferencias estilísticas habían sido observadas varias décadas antes por Larco (1948) y fueron omitidas por la autora.

Las recientes evidencias extraídas de la Huaca del Sol (Tufinio et al. 2013, 2014) y del núcleo urbano Moche (Zavaleta et al. 2013) han relevado cerámica Huari, Cajamarca Clásico, Cajamarca Costeño y Casma Impreso Local. Ello sugiere una corta pero existente fase de transición durante el Horizonte Medio en el valle de Moche, la cual merece mayor atención en el futuro.

Por otra parte, lo que Larco denomina como Huari Norteño B del Período Fusional Medio corresponde a lo que se conoce como Tanguche Temprano del valle de Santa, que se ha registrado en el núcleo urbano (Meneses et al. 2014, Zavaleta et al. 2014). En su libro Los mochicas, Larco (1939) denomina al Lambayeque como estilo Abigarrado. Este estilo tampoco se halla en Huacas de Moche, pero sí en Chan Chan, y fue el mismo que Mackey confundió como Chimú Temprano. Con respecto a la fase Fusional Tardía, Larco (1939) hace hincapié en la cerámica Cajamarca, la que también ha sido encontrada en la Huaca del Sol (Tufinio et al. 2013, 2014) y en el núcleo urbano Moche (Meneses et al. 2014, Zavaleta et al. 2014). Curiosamente, esta se relaciona en muchos casos con la cerámica Tanguche Temprano. Por último, Larco (1939) señala la presencia de un estilo Fusional Huari-Lambayeque, cuyas características morfológicas lo identifican claramente con el estilo Tomaval del valle de Virú (Collier 1955), correspondiente a la muestra recuperada en Huacas de Moche, sobre todo en las tumbas más tempranas del cementerio chimú de Huaca de la Luna. De esta manera, se plantea que el Chimú Temprano de Huaca de la Luna no es similar al Tanguche Temprano en el valle de Santa, ni menos al Abigarrado en Chan Chan. Tal propuesta se justifica a continuación.

El patrón funerario es el punto de partida. Si bien es cierto que la forma de entierro de cuerpos sentados y flexionados en los pozos debió ser tomada del patrón Huari (Isbell \& Korpisaari 2012), también existen evidencias moches de ella en el conjunto arquitectónico 35 (Gayoso \& Uceda 2009). En el corpus funerario que 
estudian Donnan y Mackey (1978), se puede considerar que las tumbas EC10, EC11, EC12, EC14, EC15, EC29 y EC30 guardan un patrón funerario diferente a las demás. Todos los cuerpos se encontraban sentados, pero con el tronco recostado hacia adelante y con el cráneo hacia abajo. Este mismo patrón se advierte en la tumba intrusiva encontrada en el Ambiente 6 del conjunto arquitectónico 6 (Chapdelaine et al. 1999). Otros dos casos similares fueron registrados en las excavaciones del conjunto arquitectónico 37. Se trata de dos individuos: un adulto y un niño, ambos depositados en cuclillas y con un plato de cocción oxidante sobre el cráneo (Bernier 2006). Recientemente, los Conjuntos arquitectónicos 5,46 y 48 pusieron en evidencia cuatro entierros (E5-21, E5-22, E46-7 y E48-2) cuyos cuerpos también se encontraban inclinados hacia adelante (fig. 18a) y cuya cerámica asociada correspondería a estilos Cajamarca, Casma Local y Tanguche Temprano (Meneses et al. 2014). Ese mismo año, las excavaciones del conjunto arquitectónico 47 revelaron seis tumbas intrusivas tipo pozo, cuyos cuerpos presentaban la misma posición y cerámica similar (Zavaleta et al. 2014). La tumba Tanguche de Huaca China o Choloque (valle de Santa) tenía el mismo patrón: estaba asociada a platos trípodes y un cántaro típico Tanguche Temprano (Chapdelaine \& Pimentel 2001).

Como se mencionó anteriormente, todas las tumbas del cementerio investigado contienen individuos en posición sentada con las piernas flexionadas hacia el tronco o en posición de medio loto (fig. 18b). En la muestra de Donnan y Mackey (1978), los EC13, EC16, EC17, EC18, EC19, EC21, EC22, EC23, EC24, EC25, EC26 y EC31 se observan en esta postura. La única tumba con vasijas tricolor similar a la muestra estudiada es la EC13, además de las tumbas alteradas recuperadas en el sitio Banderas (EC1 al EC7). Ello dificulta las comparaciones entre estos contextos. Sin embargo, se puede sugerir que las tumbas con los cuerpos inclinados hacia el piso no corresponden a la fase Chimú Temprano de Huaca de la Luna, sino a un período anterior, posiblemente al Tanguche Temprano.

Lamentablemente, no se dispone de un análisis completo de los cráneos de todos los contextos funerarios postmoche recuperados en el núcleo urbano para determinar si la deformación craneana tabular erecta planolámbdica y tabular erecta plano-frontal es una característica que identifica a los chimús o está vigente desde el Período de Transición. Es evidente que la pre- sencia de estas deformaciones en el cementerio chimú de Huaca de la Luna indica que se trata de un mismo grupo corporativo. Este tipo de deformaciones ha sido registrado en la cerámica Chimú y se lo ha denominado "divinidad bilobada" (Rojas 1967-1968). Curiosamente, aquellas representaciones aparecen en botellas de doble cuerpo que no han sido consignadas en la muestra, ni tampoco en excavaciones previas en las Huacas de Moche (Uhle 1913, Donnan \& Mackey 1978).

Los fechados radiocarbónicos obtenidos en el sitio El Castillo del valle de Santa sugieren que el período Tanguche Temprano oscila entre 900-1150 DC (Bélisle 2008). Para verificar la cronología chimú, se han obtenido dos primeros fechados radiocarbónicos de las tumbas E85 y E86 del cementerio chimú de Huaca de la Luna. ${ }^{1}$ En el caso de la tumba E85, esta se encontraba en el nivel más profundo de la celda $C$ de la Terraza 1 , y se obtuvo un fechado de los restos del fardo textil cuyos resultados calibrados a dos sigmas indican: 1040-1100 DC y 1120-1160 DC. La tumba E86 también se encontraba en el nivel más profundo de la celda B de la Terraza 1. El resultado calibrado a dos sigmas de restos de textil del fardo funerario señalan: 1160-1220 DC. Vale hacer hincapié en que los fechados radiocarbónicos obtenidos en el sitio para el período Moche acreditan que la ocupación moche debió extenderse hasta el 885 DC y estar asociada a cerámica de la fase IV (Uceda et al. 2008).

Estos primeros fechados demuestran que la cerámica Tricolor Chimú Temprano del cementerio investigado es más tardía que la Tanguche Temprano del valle de Santa, aun cuando pudieron haber coexistido en algún momento. De cualquier forma, queda en evidencia que se trata de dos estilos distintos que no se habrían mezclado, puesto que no se ha recuperado -hasta la fecha- una tumba asociada a cerámica de ambos estilos. Es posible que luego del abandono definitivo del sitio por parte de los moches, entre el 900 y 1100 DC, existiera un período transicional como en San José de Moro (Rucabado \& Castillo 2003), caracterizado por exhumaciones de grupos que importaban vasijas y realizaban entierros de manera desordenada en la explanada. La fase Chimú Temprano debió comenzar en 1100 DC y durar aproximadamente entre 100 a 150 años, hasta el comienzo de la fase Media. No obstante, estas conjeturas aún son muy apresuradas y se espera contar en un futuro con mayores fechados para aclararlas.

Por otra parte, es relevante que la tumba con cerámica Tricolor asociada al Tanguche Temprano de 


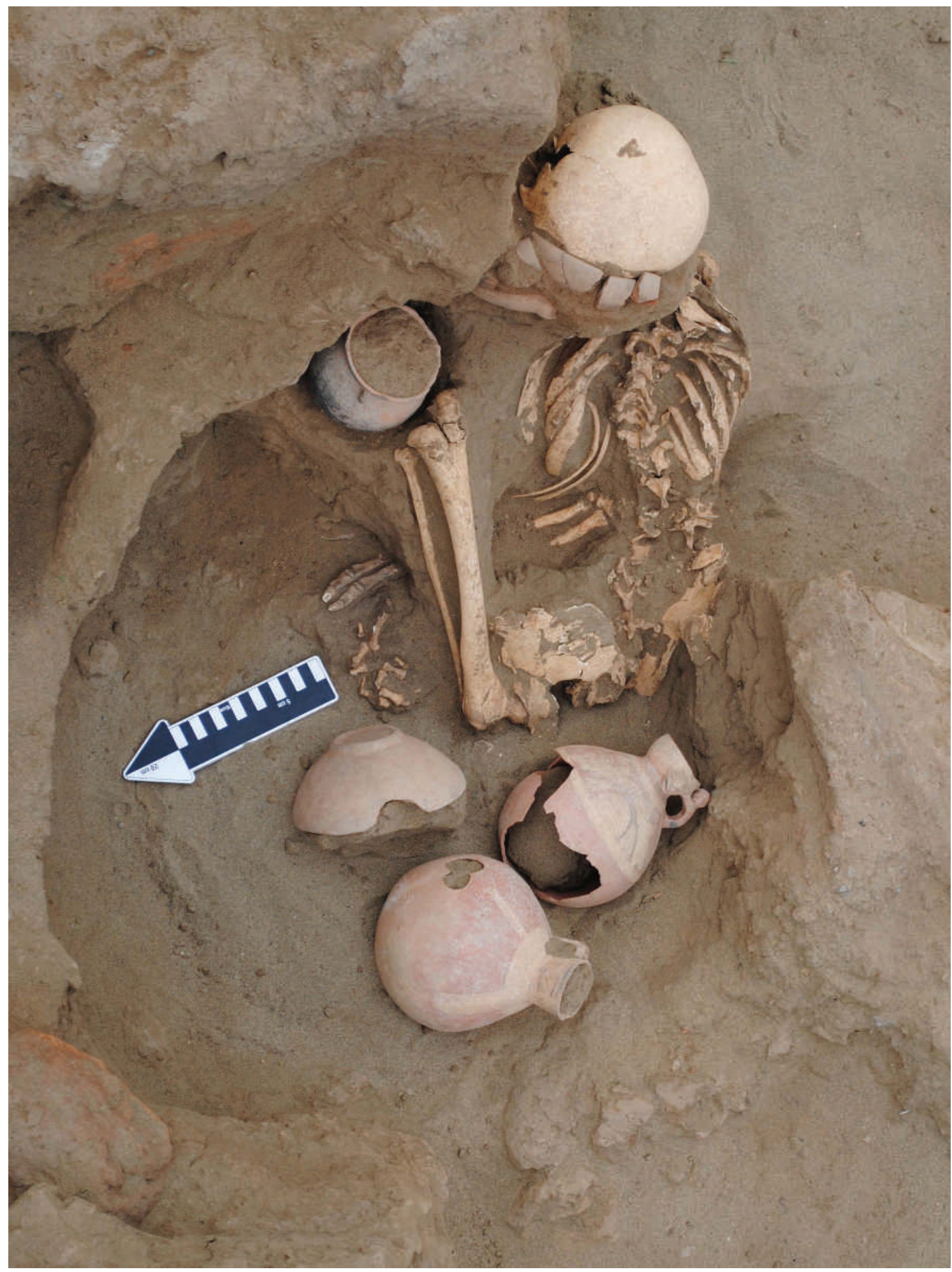

Figura 18: a) tumba Tanguche (E46-7) proveniente del núcleo urbano moche. Figure 18: a) Tanguche tomb (E46-7) found within the Moche urban center. 


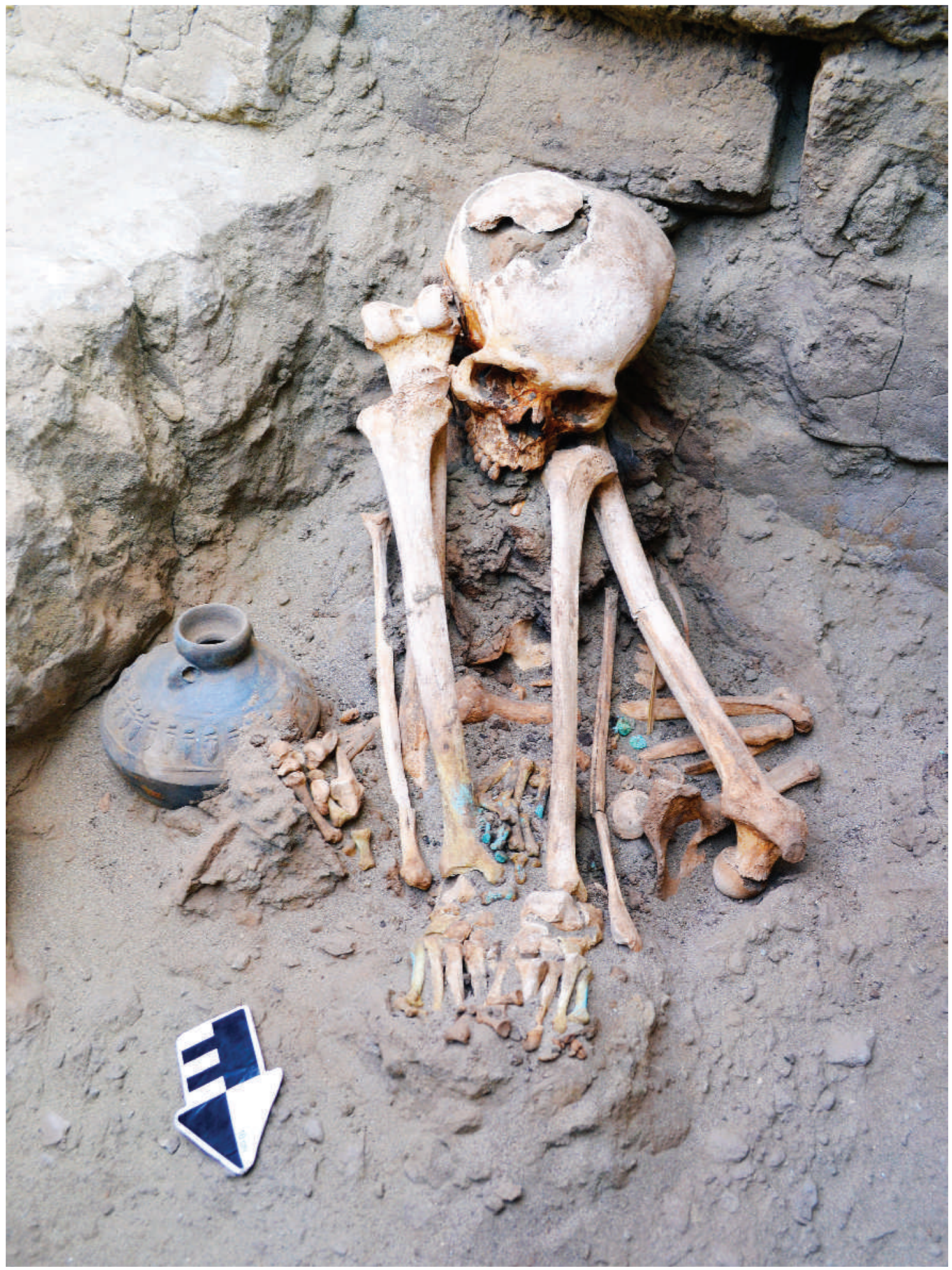

Figura 18: b) tumba Chimú Temprano (E-126) proveniente del cementerio chimú de Huaca de la Luna. Figure 18: b) Early Chimu tomb (E-126) from the Chimu cemetery in Huaca de la Luna. 
Huaca China presente platos trípodes. Algo similar se ha evidenciado en el núcleo urbano, lo cual sugiere que este estilo es acompañado de estilos conocidos, como Casma Local y Cajamarca Costeño en Jequetepeque (Rucabado \& Castillo 2003). De esta manera, se descarta tajantemente que estos tipos de vasijas se asocien al Chimú Temprano, puesto que tampoco han sido registrados en la muestra.

El Tanguche Temprano presenta formas típicas, como la olla de cuello corto, el cántaro de cuello ondulado y el cuenco con un borde inclinado por el interior (Bélisle 2008). Estas formas no se hallan en la muestra y, según los análisis de Bélisle, muchas de ellas no han sido aparentemente descubiertas para este período, lo cual sugiere que se trata de estilos alfareros distintos (fig. 19). Por otra parte, el discurso iconográfico Tanguche Temprano se caracteriza por ostentar íconos -aún remanentes- de Huari, mientras que las vasijas Chimú Temprano de Huaca de la Luna ofrecen elementos más geométricos, como rombos, triángulos, escalonados y círculos (fig. 20). Además, las vasijas con estampado impreso son poco comunes en la muestra, al contrario de lo que sucede con Tanguche Temprano, que exhibe una gran variedad.

Finalmente, el estilo Abigarrado merece un apartado, puesto que según Mackey (1985: 87): "por ahora hay suficiente evidencia para afirmar que la cerámica de la fase Chimú 1 existe en Chanchán, pese a que aún no se ha encontrado en toda la asamblea". En su afán de justificar la presencia de Chimú Temprano en la metrópoli chimú, la autora usa como referencia la cerámica recuperada en Chayhuac (Chan Chan) descrita por Kroeber (1926). Larco (1938) denominó este estilo como Abigarrado, y sobre él escribió: "En Chan Chan, en los estratos más profundos, bajo los enterramientos chimús, encontramos esta cerámica. En el valle de Chicama la hallamos al mismo nivel que la Chimú y Tiahuanaco decadente. [...] nos hace suponer que se trata de una cerámica de transición entre la mochica y la negra Chimú" (Larco 1938: 125). El corpus observado sobre este estilo es muy escaso, pero se puede apreciar que la botella asa puente se distingue por presentar doble cuerpo (rasgo que no se ha reportado hasta la fase 4 o Chimú-Inca) y contar con un soporte alto que alude a un pedestal.

Otra característica de la cerámica abigarrada es la excesiva decoración pictórica, destacando la pintura negra sobre blanco. Los motivos principales son geométricos de trazo fino y cubren la totalidad de las vasijas. Larco
(1938) también llamó a este estilo Lambayeque, cuyas evidencias en los estratos más profundos de Chan Chan han sido empleados por Segura y Shimada (2014) para asegurar la influencia Lambayeque (Sicán) Medio en esta parte del valle.

En el valle de Chicama, como lo mencionó Larco (1938), también se encuentra este estilo. En el área lateral este de la Huaca Cao se recuperó una botella de doble cuerpo que merece mayor atención (Mujica et al. 2007). Recientes investigaciones en la Huaca La Ternera 2, cerca de Chan Chan, han revelado una tumba con características típicas chimú, cuyas vasijas podrían asociarse con la fase Temprana (Horna et al. 2009). Lamentablemente, las vasijas no exhiben evidencias diagnósticas para asegurar a qué fase corresponden.

Entonces, ¿el estilo Tricolor del cementerio chimú de Huaca de la Luna debe ser considerado Chimú Temprano? Probablemente sí: existe una continuidad de tumbas entre las cuatro fases para este cementerio. Sin embargo, se pone en tela de juicio la ausencia de este estilo en los estratos más profundos de Chan Chan y su relación con el estilo Abigarrado ¿Serán estilos contemporáneos o uno es más tardío que el otro? Es muy probable que durante esta fase existieran estilos locales relacionados con pequeños grupos o cacicazgos. El estilo Abigarrado no ha sido registrado hasta hoy en las Huacas del Sol y de la Luna, lo que sugiere que es propio de la margen norte del río Moche y del valle de Chicama. Por su parte, el estilo Tomaval (Chimú Temprano) sería propio de la margen sur del valle de Moche y está presente en los valles de Virú y Chao, con algunas evidencias en el valle de Santa. Pudo haber existido una movilidad de grupos y estilos alfareros propios de este período, pues aún no existía un estado territorial bien establecido. Estas conjeturas deberán ser corroboradas con futuras investigaciones y con ayuda de fechados radiocarbónicos para los contextos en cuestión, especialmente en Chayhuac (Chan Chan).

\section{LA CERÁMICA CLÁSICA Y DE COCCIÓN REDUCTORA CHIMÚ}

Durante la fase Chimú Medio, las tumbas que estudian Donnan y Mackey (1978) provienen de Huacas de Moche, pero algunas de ellas posiblemente no se correlacionan con este período. Tales son los casos de las MC5, MC6 y MC10, que podrían ser tumbas previas a la primera 


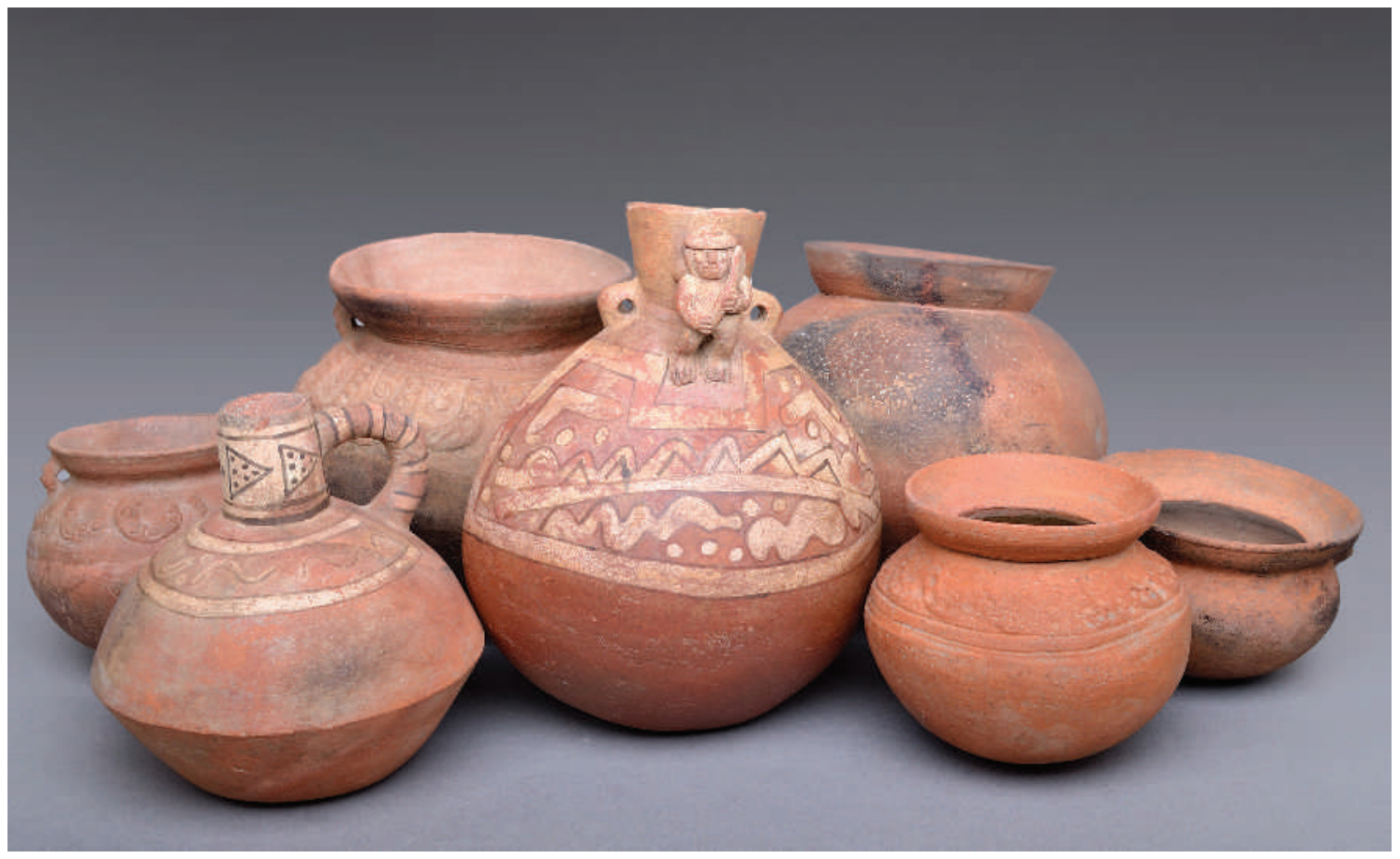

Figura 19. Vasijas del estilo Tricolor Tanguche provenientes del núcleo urbano moche. Figure 19. Tricolor Tanguche-style vases found within the Moche urban center.

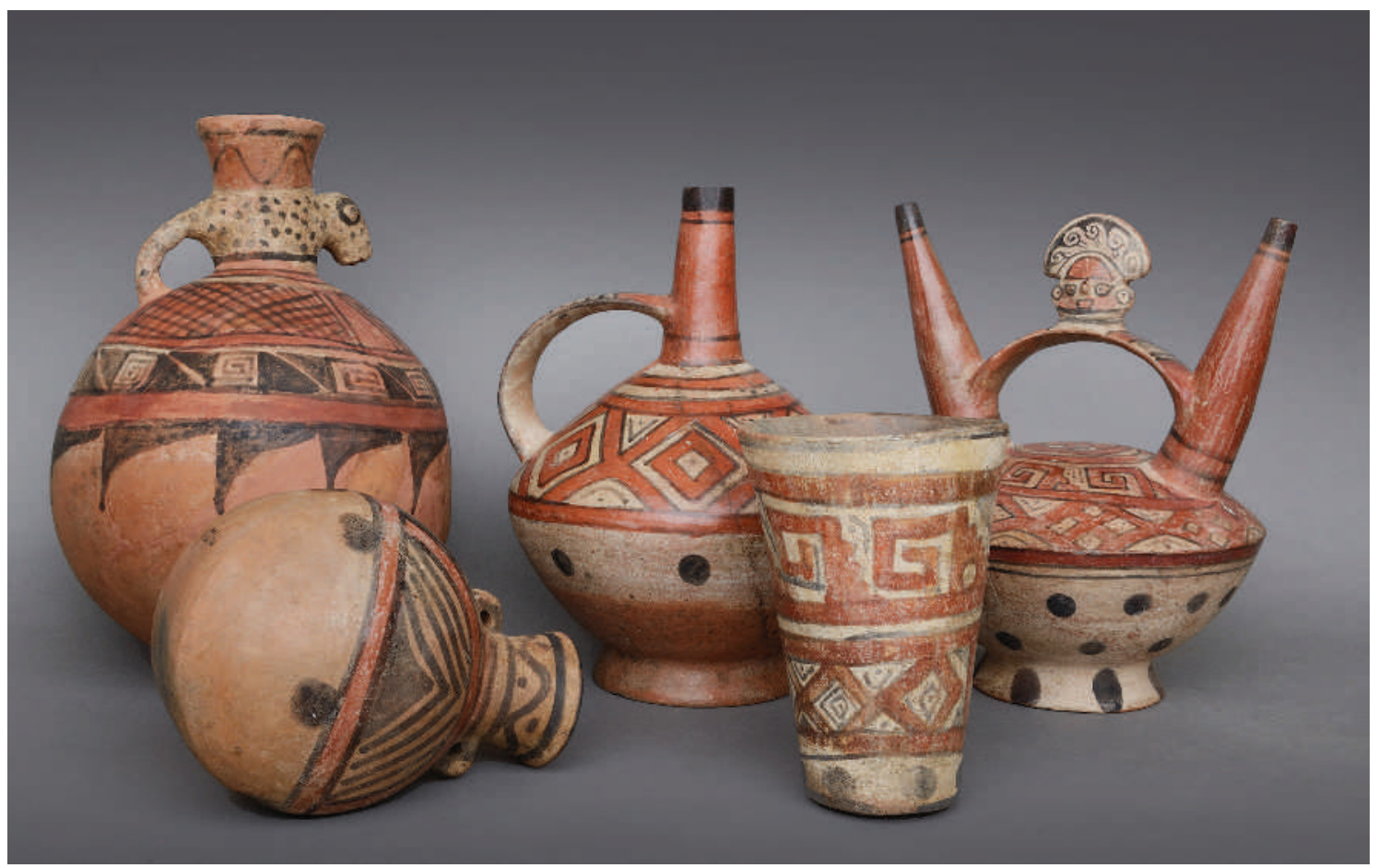

Figura 20. Vasijas del estilo Tricolor correspondientes a la fase Chimú Temprano. Figure 20. Tricolor-style vases from the Early Chimu Period. 
fase, quizás relacionadas con el período transicional. En el caso del MC8, se trata de un cántaro con el labio muy evertido y con decoración paleteada, lo que la inscribiría en la tercera fase. Finalmente, las MC2 y MC9 presentan platos con base anular que parecen ser típicos de la fase Temprana. El resto de las tumbas contienen formas que se corresponden evidentemente con las ofrecidas en nuestra tipología. De esta manera, se respalda lo señalado por los autores: "an increase in the frequency of large jars placed in Middle Chimu graves compared to Early Chimu graves" (Donnan \& Mackey 1978: 340). Al parecer, por esta razón se suelen encontrar vasijas, especialmente cántaros, de grandes dimensiones y cocción reductora en la fase Media.

En la fase Chimú Tardío, Donnan y Mackey (1978) presentan cuatro tumbas provenientes de Chan Chan y Huacas de Moche. Estas se podrían relacionar con las formas registradas en el cementerio estudiado en este artículo, pero no se puede entrar en mayores discusiones. Lockard (2008) ha recuperado cerámica de pasta negra en estructuras residenciales de Galindo que fueron habitadas entre 1416-1435 DC (según los fechados radiocarbónicos). Por otra parte, en Jequetepeque, Prieto (2008) elabora una tipología muy compleja de las formas Chimú Tardío recuperadas en el Área 35 de San José de Moro. Lamentablemente, no se cuenta con datos estadísticos para entender la proporción de las muestras analizadas; con todo, al igual que en Galindo, las ollas de cuello carenado forman parte de las formas típicas de este período, dato que podría indicar su pertenencia a esta fase.

Finalmente, las evidencias de la fase Chimú-Inca han sido reportadas al sur de la Huaca del Sol por Uhle (1913). Es muy probable que se trate de un cementerio chimú o chimú-inca que actualmente está invadido por los campos agrícolas. Entre las piezas recuperadas por Uhle, destaca la presencia de aríbalos, forma que hasta la fecha no ha sido nuevamente registrada en todo el complejo. Entre las tumbas que Donnan y Mackey (1978) asocian a esta fase, ninguna provenía de Huacas de Moche, y se considera que algunas de ellas podrían estar correlacionadas con la fase anterior. La tumba CI1, procedente de Rivero (Chan Chan), así como CI9 a CI11, de Caballo Muerto, son las que mejor se corresponden con este período. En la muestra estudiada, se pueden apreciar platos de formas incas típicas (Bauer 2001), pero se diferencian por estar cocidas en horno cerrado y sin decoración pictórica. Otra característica de esta fase es que los golletes de las botellas asa estribo son netamente biselados y no tubulares, como en las fases anteriores. Por otra parte, en el centro de manufactura de cerámica de Cañoncillo ubicado en el valle de Jequetepeque, se han reportado también las formas analizadas (Donnan 1997). El autor concluye: "It is clear, however, that local Chimu-and Inka-style ceramics were both produced at the site" (Donnan 1997: 53). Es muy probable que los alfareros chimús hayan aprendido las formas incas e intentaran simularlas con los recursos locales. Al igual que en las anteriores, se necesitan mayores intervenciones y fechados radiocarbónicos para aclarar esta fase.

La evidencia sobre la producción alfarera para la sociedad chimú ha sido muy bien registrada y discutida para las últimas fases. Por ejemplo, en el valle de Lambayeque, Tshauner (2009) ha discutido ampliamente la distribución de la cerámica de Pampa de Burros y ha planteado un largo debate con respecto al papel político que jugaba la cerámica en las sociedades pasadas. Por otra parte, en el valle de Jequetepeque, Donnan (1997) y Prieto (2008) han sostenido largas discusiones que permiten tener una visión amplia sobre los objetos utilitarios. Aparentemente, estos no fueron controlados por el Estado y sugieren la presencia de olleros itinerantes, tema ampliamente abordado a nivel etnográfico por Gabriel Ramón (2013) con la denominación de alfareros golondrinos.

Desde las evidencias ofrecidas en este trabajo, se considera inoportuno entrar en mayores debates sobre los grupos alfareros. La ausencia -hasta la fecha- de talleres de alfareros de cerámica Chimú en el valle de Moche es el principal problema. En especial, de talleres alfareros asociados a la fase Temprana, la que ocupa la parte más importante de estos comentarios. Por tal razón, no se considera ético realizar inferencias a priori que terminen con el tiempo en relaciones espurias.

A modo de conclusión, el presente artículo no busca generar más discusiones sobre la funcionalidad y el uso de cada elemento analizado, sino aportar nuevos datos interpretativos relacionados con la tipología y seriación de la cerámica Chimú en el valle de Moche. Estos datos deben ser debatidos y consultados por los investigadores especializados para mejorar a futuro la cronología relativa de cuatro fases de la sociedad chimú. 
Reconocimientos El autor quiere agradecer al Dr. Santiago Uceda Castillo, quien fue director del Proyecto Arqueológico Huacas del Sol y de la Luna (1991-2018). Mi profundo agradecimiento por ser mi guía académico y amigo todos estos años. Este trabajo fue realizado con su apoyo y motivación que causaba hacia la investigación. A los colegas que laboran y laboraron en el proyecto, quienes apoyaron arduamente en el registro gráfico del material cerámico y en los extensos debates que permitieron mejorar el manuscrito. Las fotografías pertenecen al Proyecyo Arqueológico Huacas del Sol y de la Luna.

\section{NOTAS}

${ }^{1}$ Los fechados Ams se realizaron gracias al apoyo del Dr. John W. Verano (Department of Anthropology, Tulane University) en el Laboratorio Beta Analytic Inc.

\section{REFERENCIAS}

BAUER, B. 2001. Las antiguas tradiciones alfareras de la región del Cuzco. Cuzco: Centro Bartolomé de Las Casas.

Bélisle, V. 2008. El Horizonte Medio en el valle de Santa: continuidad y discontinuidad con los mochicas del Intermedio Temprano. En Arqueología mochica: nuevos enfoques. Actas del Primer Congreso Internacional de Jóvenes Investigadores de la Cultura Mochica, L. J. Castillo, H. Bernier, G. Lockard \& J. Rucabado, Eds., pp. 17-31. Lima: Pontificia Universidad Católica del Perú-Instituto Francés de Estudios Andinos.

Bernier, H. 2006. Investigaciones en el conjunto arquitectónico 37, centro urbano moche. En Investigaciones en la Huaca de la Luna 2000, S. Uceda, E. Mujica \& R. Morales, Eds., pp. 185-215. Trujillo: Facultad de Ciencias Sociales, Universidad Nacional de Trujillo.

Castillo, F. 2013. Descifrando un culto a los ancestros. En ArKeopáticos. Textos sobre arqueología y patrimonio 1 (3): 13-39. México. https://www.academia.edu/4117446/ Descifrando_un_culto_a_los_ancestros $>$ [consultado 21-07-2018].

Castillo, L. 2000. La presencia wari en San José de Moro. Boletín de Arqueología PUCP 4: 143-179. Lima.

Chapdelaine, C. \& Pimentel, V. 2001. Informe del proyecto arqueológico PSUM (Proyecto Santa de la Universidad de Montreal). La presencia moche en el valle de Santa, costa norte del Perú -junio, julio y agosto 2000-. Montreal: Faculté d'arts et des sciences de l'Université de Montréal.

Chapdelaine, C., Bernier, H. \& Bracamonte, F. 1999. Una tumba intrusiva chimú temprano en el sector urbano del sitio Moche. Revista Arqueológica Sian 8: 28-34. Trujillo. Clarke, D. 1984. Arqueología analítica. Barcelona: Bellaterra.
Collier, D. 1955. Cultural chronology and change as reflected in the ceramics of the Viru Valley, Peru. Chicago: Chicago Natural History Museum.

Conrad, G. 1980. Plataformas funerarias. En Chan Chan, metrópoli chimú, R. Ravines, Ed., pp. 217-230. Lima: Instituto de Estudios Peruanos.

DAY, K. 1980. Las ciudadelas de Chanchán. En Chan Chan, metrópoli chimú, R. Ravines, Ed., pp. 155-158. Lima: Instituto de Estudios Peruanos.

Donnan, C. 1997. A Chimu-Inka ceramic-manufacturing center from the north coast of Peru. Latin American Antiquity 8 (1): 30-54. Cambridge.

Donnan, C. 2011. Moche substyles: keys to understanding Moche political organization. Boletín del Museo Chileno de Arte Precolombino 16 (1): 105-118. Santiago.

Donnan, C. \& Mackey, C. 1978. Ancient burial patterns of the Moche valley, Peru. Austin: University of Texas Press.

Floreano, D. 2016. Estudios isotópicos para establecer la dieta de los camélidos en la ocupación post Moche en Plaza 1, Huaca de la Luna, Trujillo-Perú. Revista Archaeobios 10 (1): 5-36. Trujillo.

Ford, J. \& Willey, G. 1949. Surface survey of the Virú valley, Peru. Anthropological Papers of the American Museum of Natural History 43 (1). New York.

Gamarra, N. \& Gayoso, H. 2008. La cerámica doméstica en huacas de Moche: un intento de tipología y seriación. En Arqueología mochica: nuevos enfoques. Actas del Primer Congreso Internacional de Jóvenes Investigadores de la Cultura Mochica, L. J. Castillo, H. Bernier, G. Lockard \& J. Rucabado, Eds., pp. 187-202. Lima: Fondo Editorial de la Pontificia Universidad Católica del Perú-Instituto Francés de Estudios Andinos.

GamboA, J. \& UcedA, S. 2008. Entierros chimú en la Plaza 1 de Huaca de la Luna. En Investigaciones en la Huaca de la Luna 2002, S. Uceda, E. Mujica \& R. Morales, Eds., pp. 223-236. Trujillo: Facultad de Ciencias Sociales de la Universidad Nacional de Trujillo-Patronato Huacas del valle de Moche.

Gayoso, H. \& UCEdA, S. 2009. Cuando los muertos hablan en Moche. Los patrones funerarios en un conjunto arquitectónico del núcleo urbano. En Proyecto arqueológico Huaca de la Luna. Informe técnico 2008, S. Uceda \& R. Morales, Eds., pp. 480-505. Trujillo: Facultad de Ciencias Sociales de la Universidad Nacional de Trujillo.

Gayoso, H. 2016. Los maestros del barro: cerámica y ceramistas de la ciudad de las Huacas del Sol y de la Luna. En Investigaciones en la Huaca de la Luna 2015, S. Uceda, R. Morales \& C. Rengifo, Eds., pp. 289-316. Trujillo: Facultad de Ciencias Sociales de la Universidad Nacional de Trujillo-Patronato Huacas del valle de Moche.

Horna, N., Chiguala, J., Centurión, J. \& Lozano, J. 2009. Cuatro sitios Chimú en la parte baja del valle de Moche: evidencias de los antiguos señoríos de Guamán y Chicán. Revista Arqueológica Sian 20: 3-16. Trujillo. 
Isbell, W. \& KorpisaARI, A. 2012. Burial in the Wari and the Tiwanaku heartlands: similarities, differences, and meanings. Diálogo Andino 39: 91-122.

Kroeber, A. 1926. Archaeological explorations in Peru. Part I: ancient pottery from Trujillo. Field Museum of Natural History, Anthropology Memoirs 2 (1). Chicago.

LARCO, R. 1938. Los mochicas, tomo 1. Lima: La Crónica y Variedades S. A.

LARCo, R. 1939. Los mochicas, tomo 2. Lima: La Crónica y Variedades S. A.

Larco, R. 1945. Los mochicas (Pre-Chimu de Uhle y Early Chimu de Kroeber). Buenos Aires: Sociedad Geográfica Americana.

LARCo, R. 1948. Cronología arqueológica del norte del Perú. Buenos Aires: Biblioteca del Museo de Arqueología Rafael Larco Herrera-Hacienda Chiclín-Sociedad Geográfica Americana.

LocKard, G. 2008. La ocupación Chimú en Galindo: un asentamiento rural en el corazón del Reino Chimor. Revista Arqueológica Sian 19: 2-17. Trujillo.

Lumbreras, L. 2005. Arqueología y sociedad. Lima: indea.

Mackey, C. 1985. La cerámica chimú a fines del horizonte medio. Revista del Museo Nacional XLVII: 73-91. Lima.

MACKey, C. 2013. Estrategias administrativas del Estado Chimú a nivel provincial. Revista del Museo de Arqueología, Antropología e Historia 12: 153-88. Trujillo.

Manrique, E. 2001.Guía para el estudio y tratamiento de la cerámica precolombina. Lima: CONCYTEC.

MEjíA, J. 2014. Anexo 1. Aspectos paleopatológicos y paleográficos. En Proyecto arqueológico Huaca de la Luna. Informe técnico 2013, S. Uceda \& R. Morales, Eds., pp. 87-159. Trujillo: Facultad de Ciencias Sociales de la Universidad Nacional de Trujillo.

Meneses, J., Robles, A., Vega, R., Chávez, F., Cruz, D., RodrígueZ, L., Rojas, H. \& TANTE, F. 2014. Excavaciones en los conjuntos arquitectónicos 5, 46, 48 y 49: configuración y ordenamiento espacial de los conjuntos del sur. En Proyecto arqueológico Huaca de la Luna. Informe técnico 2013, S. Uceda \& R. Morales, Eds., pp. 351-404. Trujillo: Facultad de Ciencias Sociales de la Universidad Nacional de Trujillo.

Mujica, E., Franco, R., Gálvez, C., Quilter, J., Murga, A., Gamarra, C.,Ríos, V., Lozada Alcalde, S., Verano J. \& Aveggio M. 2007. El Brujo. Huaca Cao, centro ceremonial moche en el valle de Chicama / Huaca Cao, A Moche Ceremonial Center in the Chicama Valley. Lima: Fundación Wiese-AFP Integra.

Orbegoso, M., Castillo, F., Ramírez, L. \& Chumbe, L. 2013. Excavaciones en la plaza 1 de Huaca de la Luna. En Proyecto arqueológico Huaca de la Luna. Informe técnico 2012, S. Uceda \& R. Morales, Eds., pp. 85-153. Trujillo: Facultad de Ciencias Sociales de la Universidad Nacional de Trujillo.

Orbegoso, M., Chumbe, L. \& Ramírez, L. 2012. Excavaciones en el frontis norte y en la plaza 1 de Huaca de la Luna. En
Proyecto arqueológico Huaca de la Luna. Informe técnico 2011, S. Uceda \& R. Morales, Eds., pp. 129-212. Trujillo: Facultad de Ciencias Sociales de la Universidad Nacional de Trujillo.

Orbegoso, M., Gómez, J., Chumbe, L., Ramírez, L. \& BArboZA, S. 2011. Excavaciones en el frontis norte y en la plaza 1 de Huaca de la Luna. En Proyecto arqueológico Huaca de la Luna. Informe técnico 2010, S. Uceda \& R. Morales, Eds., pp. 51-124. Trujillo: Facultad de Ciencias Sociales de la Universidad Nacional de Trujillo.

Piminchumo, V. 2004. La cultura Chimú: prólogo a nuevos datos. En Desarrollo arqueológico de la costa norte del Perú, volumen 2, L. Valle, Ed., pp. 7-16. Trujillo: sian.

Prieto, G. 2008. Cerámica utilitaria Chimú de San José de Moro: tipología de formas y modelos interpretativos. Revista del Museo de Arqueología, Antropología e Historia 10: 111-154. Trujillo.

RAMón, G. 2013. Los alfareros golondrinos. Productores itinerantes en los Andes. Lima: Instituto Francés de Estudios Andinos-Sequilao.

RAvines, R. 1980a. La ciudad y sus habitantes. En Chan Chan, metrópoli chimú, R. Ravines, Ed., pp. 105-129. Lima: Instituto de Estudios Peruanos.

Ravines, R. 1980b. Religión y culto a los muertos. En Chan Chan, metrópoli chimú, R. Ravines, Ed., pp. 211-216. Lima: Instituto de Estudios Peruanos.

Renfrew, C. \& Bahn, P. 1998. Arqueología. Teorías, métodos y práctica. Madrid: Akal.

Rojas, C., Castillo, F., Mejía, J., Paredes, R., Asmat, W., Ávalos, E., Bocanegra, S., Marreros, J. \& Tufinio, K. 2014. Excavaciones en la plaza 1 de Huaca de la Luna. En Proyecto arqueológico Huaca de la Luna. Informe técnico 2013, S. Uceda \& R. Morales, Eds., pp. 87-159. Trujillo: Facultad de Ciencias Sociales de la Universidad Nacional de Trujillo.

Rojas, P., 1967-1968. Estudio de las imágenes con cabezas bilobadas de la cerámica Chimú y Chancay. Revista del Museo Nacional, tomo xxx: 295-311. Lima.

Rucabado, J. \& Castillo, L. 2003. El Período Transicional en San José de Moro. En Moche: hacia el final del milenio. Actas del Segundo Coloquio sobre la Cultura Moche, Trujillo, 1 al 7 de agosto de 1999, S. Uceda \& E. Mujica, Eds., pp. 15-42. Lima: Universidad Nacional de Trujillo-Pontificia Universidad Católica del Perú.

Segura, R. \& Shimada, I. 2014. La interacción Sicán Mediocosta central, hacia 1000 DC. En Cultura Sicán. Esplendor preincaico de la costa norte, I. Shimada, Ed., pp. 303-322. Lima: Fondo Editorial del Congreso del Perú.

Tschauner, H. 2009. "“Los olleros no son del Inka», especialización artesanal y economía política en los Andes: el caso de los alfareros de la Pampa de Burros". Revista de Antropología 20: 261-296. Chile.

Tufinio, M. 2012. Excavaciones durante el 2003 en la fachada norte y plaza 1 de Huaca de la Luna, y nuevas evidencias 
chimúes. En Investigaciones en la Huaca de la Luna 2003, S. Uceda, E. Mujica \& R. Morales, Eds., pp. 39-66. Trujillo: Facultad de Ciencias Sociales de la Universidad Nacional de Trujillo-Patronato Huacas del valle de Moche.

Tufinio, M., Chávarri, H., Gamboa, P. \& Velásquez, V. 2014. Excavaciones en la sección 4 de Huaca del Sol. En Proyecto arqueológico Huaca de la Luna. Informe técnico 2013, S. Uceda \& R. Morales, Eds., pp. 177-257. Trujillo: Facultad de Ciencias Sociales de la Universidad Nacional de Trujillo.

Tufinio, M., Chávarri, H., Veja, R. \& Gamboa, P. 2013. Excavaciones en la sección 2 de Huaca del Sol. En Proyecto arqueológico Huaca de la Luna. Informe técnico 2012, S. Uceda \& R. Morales, Eds., pp. 177-260. Trujillo: Facultad de Ciencias Sociales de la Universidad Nacional de Trujillo.

UCEDA, S. 2008. Rituales funerarios de los reyes en una maqueta Chimú. En Señores de los reinos de la Luna. Colección Arte y Tesoros del Perú, K. Makowski, Comp., pp. 314-335. Lima: Banco de Crédito del Perú.

UCEDA, S. 2010. Los contextos urbanos de producción artesanal en el complejo arqueológico de las Huacas del Sol y de la Luna. Bulletin de l'Institut Français d'Études Andines 39 (2): 243-299. Lima.

Uceda, S., Chapdelaine, C. \& Verano, J. 2008. Fechas radiocarbónicas para el complejo arqueológico Huacas del Sol y de la Luna: una primera cronología del sitio. En Investigaciones en la Huaca de la Luna 2001, S. Uceda, E. Mujica \& R. Morales, Eds., pp. 213-223. Trujillo: Facultad de Ciencias Sociales de la Universidad Nacional de Trujillo-Patronato Huacas del Valle de Moche.
Uhle, M. 1913. Die Ruinen von Moche. Journal de la Société des Américanistes de Paris 10 (1) : 95-117. París.

WiLson, D. 1988. Prehispanic settlement patterns in the Lower Santa valley, Perú: a regional perspective on the origins and development of complex north coast society. Washington DC: Smithsonian Institution Press.

Zavaleta, L., Sernaqué, A., Zagastizábal, D., Arancibia, K., Bermeo, F., Gómez, L., Loyola, T. \& Villacorta, L. 2014. Cambios sociales y políticos en el Moche Tardío y la configuración de un conjunto administrativo en el Núcleo Urbano del complejo arqueológico Huaca del Sol y Luna. En Proyecto arqueológico Huaca de la Luna. Informe técnico 2013, S. Uceda \& R. Morales, Eds., pp. 261-350. Trujillo: Facultad de Ciencias Sociales de la Universidad Nacional de Trujillo.

Zavaleta, L., Sernaqué, A., Zagastizábal, D., Barboza, C., Mariño, D., Muñoz, J., Novoa, D., Palomino, E. \& RodríGUEZ, D. 2013. Excavaciones en el sector noreste del núcleo urbano Moche: contextos funerarios y su relación con las plataformas y la plaza. En Proyecto arqueológico Huaca de la Luna. Informe técnico 2012, S. Uceda \& R. Morales, Eds., pp. 263-362. Trujillo: Facultad de Ciencias Sociales de la Universidad Nacional de Trujillo. 